\title{
Therapeutic Applications of Multifunctional Nanozymes
}

\author{
Liu, Xiaoli; Gao, Yuan; Chandrawati, Rona; Hosta-Rigau, Leticia
}

Published in:

Nanoscale

Link to article, DOI:

10.1039/C9NR06596B

Publication date:

2019

Document Version

Peer reviewed version

Link back to DTU Orbit

Citation (APA):

Liu, X., Gao, Y., Chandrawati, R., \& Hosta-Rigau, L. (2019). Therapeutic Applications of Multifunctional Nanozymes. Nanoscale, 11, 21046-21060. https://doi.org/10.1039/C9NR06596B

\section{General rights}

Copyright and moral rights for the publications made accessible in the public portal are retained by the authors and/or other copyright owners and it is a condition of accessing publications that users recognise and abide by the legal requirements associated with these rights.

- Users may download and print one copy of any publication from the public portal for the purpose of private study or research.

- You may not further distribute the material or use it for any profit-making activity or commercial gain

- You may freely distribute the URL identifying the publication in the public portal

If you believe that this document breaches copyright please contact us providing details, and we will remove access to the work immediately and investigate your claim. 


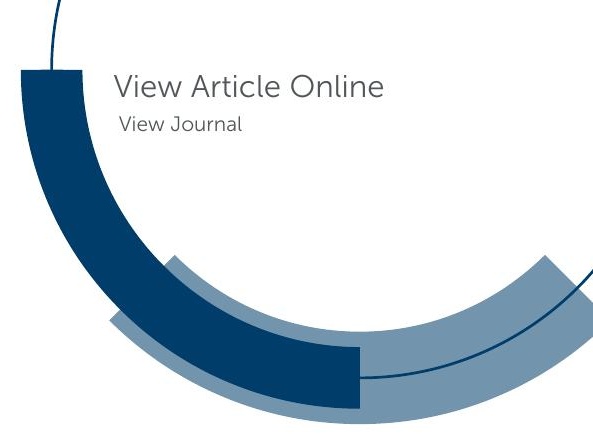

\section{Accepted Manuscript}

This article can be cited before page numbers have been issued, to do this please use: X. Liu, Y. Gao, R.

Chandrawati and L. Hosta-Rigau, Nanoscale, 2019, DOI: 10.1039/C9NR06596B.
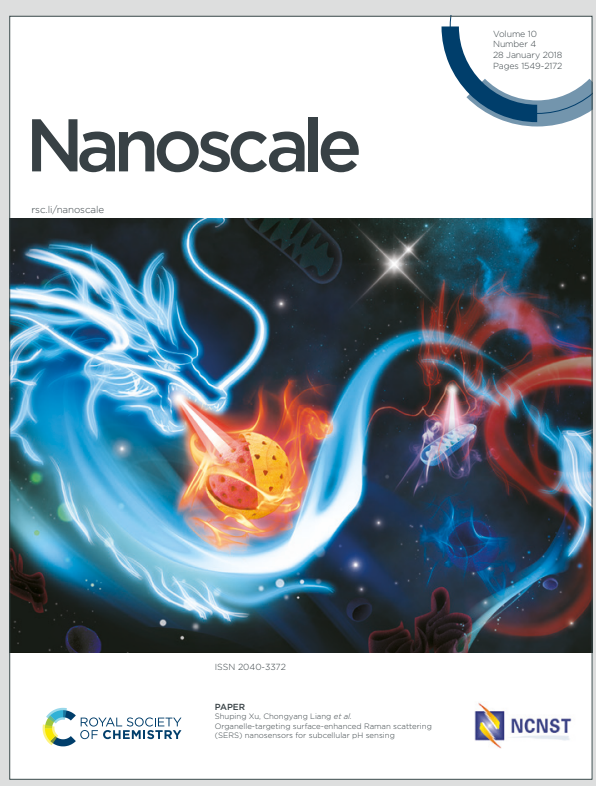

This is an Accepted Manuscript, which has been through the Royal Society of Chemistry peer review process and has been accepted for publication.

Accepted Manuscripts are published online shortly after acceptance, before technical editing, formatting and proof reading. Using this free service, authors can make their results available to the community, in citable form, before we publish the edited article. We will replace this Accepted Manuscript with the edited and formatted Advance Article as soon as it is available.

You can find more information about Accepted Manuscripts in the Information for Authors.

Please note that technical editing may introduce minor changes to the text and/or graphics, which may alter content. The journal's standard Terms \& Conditions and the Ethical guidelines still apply. In no event shall the Royal Society of Chemistry be held responsible for any errors or omissions in this Accepted Manuscript or any consequences arising from the use of any information it contains. 
Received 00th January 20xx, Accepted 00th January 20xx DOI: $10.1039 / \times 0 \times x 00000 x$

\title{
Therapeutic Applications of Multifunctional Nanozymes
}

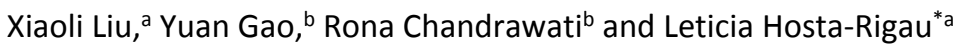 \\ Nanozymes, which are functional nanomaterials with enzyme-like characteristics, have emerged as a highly-stable and \\ low-cost alternative to natural enzymes. Apart from overcoming the limitations of natural enzymes (e.g., high cost, low \\ stability or complex production), nanozymes are also equipped with the unique intrinsic properties of nanomaterials such \\ as magnetism, luminiscence or near infrared absorbance. Therefore, the development of nanozymes exhibiting additional \\ functions to their catalytic activity has opened up new opportunities and applications within the biomedical field. To \\ highlight the progress in the field, this review summarizes the novel applications of multifunctional nanozymes in various \\ biomedical-related fields ranging from cancer diagnosis, cancer and antibacterial therapy to regenerative medicine. Future \\ challenges and perspectives that may advance nanozyme research are also discussed at the end of the review.
}

\section{Introduction}

Enzymes are biological catalysts that play a central role in many chemical and biological processes. Enzyme-catalysed reactions are highly selective towards their substrates and have excellent catalytic efficiency. However, naturally occurring enzymes have intrinsic shortcomings such as low stability, high cost, and complex production.

Nanozymes are a new type of functional nanomaterials displaying enzyme-like activity that possess several advantages over natural enzymes, including enhanced stability and robustness towards harsh conditions. ${ }^{1-6}$ They are a new generation of artificial enzymes and, the term "nanozyme", has been introduced to distinguish these novel nanomaterials exhibiting intrinsic enzyme-like properties from other nanocomplexes such as externally immobilized enzymes. ${ }^{4,7-9}$ Scheme 1 shows a typical example of a nanozyme displaying both catalytic activity (e.g., peroxidase-like activity) and intrinsic properties of nanomaterials (e.g., paramagnetic properties).

Compared to natural enzymes, nanozymes are produced in an easier and cost-efficient manner. ${ }^{4}$ Additionally, their catalytic activity can be enhanced to be comparable to that of natural enzymes by modulating their sizes, morphologies or compositions. ${ }^{9-12}$ Furthermore, nanozymes can be equipped with extra features not present in natural enzymes such as a large surface area, responsiveness towards external stimuli or size-, shape- and composition-dependent catalytic activities. ${ }^{4}$ Due to these advantages and, as a result of the burgeoning development of the nanotechnology field, in recent years nanozymes have received a great deal of attention. As such,

a. Department of Health Technology, Centre for Nanomedicine and Theranostics, DTU Health Tech, Technical University of Denmark, 2800 Lyngby, Denmark.

b. School of Chemical Engineering and Australian Centre for Nanomedicine, The

University of New South Wales (UNSW Sydney), Sydney, NSW 2052, Australia. the enzyme-like properties of a variety of nanomaterials spanning from noble metals, ${ }^{13-15}$ transition metal oxides ${ }^{16-20}$ or carbon-based materials ${ }^{21-24}$ have been explored. Also, their potential in various fields ranging from biosensor development, environmental remediation, ${ }^{25,26}$ diagnosis, ${ }^{27,28}$ therapeutics ${ }^{29,30}$ or tissue engineering ${ }^{31,32}$ has been demonstrated.

Several excellent reviews have been recently published documenting work related to nanozymes and their biomedical applications. In particular, Qu and co-workers discussed the catalytic mechanisms of nanozymes, ways to tune catalytic activities, and progresses of nanozymes in the field of biosensing, environmental protection, and disease treatments. ${ }^{33}$ Liang and Yan compared nanozymes, natural enzymes, and nanomaterial-based catalysts and discussed the unique properties of nanozymes in disease diagnosis and therapy. ${ }^{34}$ Wei and colleagues reviewed different classes of nanozymes and provided an overview of their application in biomedical imaging and theranostics. ${ }^{8}$ Cai and co-workers provided a specific review on nanozymes with single- and multiple-substrate mechanisms. ${ }^{6}$

Besides catalytic activity, nanozymes exhibit additional functionalities such as magnetic properties, luminescence or near-infrared (NIR) absorption, thus rendering nanomaterials with multiple intrinsic functions. In the past decade, the development of multifunctional nanozymes has resulted in remarkable achievements in biomedical engineering and disease treatment. Multifunctional artificial enzymes provide high-performance platforms and show promising potential in several biomedical fields ranging from diagnosis, cancer or anti-bacterial therapy.

Herein, we focus on highlighting the advantages of synergizing the multiple intrinsic functions of nanozymes and discuss representative therapeutic applications from the last five years. Finally, the current challenges and future directions in the field are examined. 


\section{Multifunctional nanozymes in disease diagnosis and drug delivery}

\subsection{Cancer diagnosis and therapy}

Cancer is a worldwide mortal sickness which has become a major public concern. It is widely acknowledged that cancer early identification and detection is of particular relevance for patients' survival.

Amongst different diagnostic methods, immunohistochemistry (IHC) has emerged as a powerful tool. IHC is a technique that employs antibodies to localize specific molecules expressed by tumours, thus providing the basis for their molecular characterization. ${ }^{35-37}$ One of the most common methods employed in IHC consists of conjugating the enzyme horseradish peroxidase (HRP) to an antibody targeting specific tumour biomarkers. At that particular location and, in the presence of hydrogen peroxide $\left(\mathrm{H}_{2} \mathrm{O}_{2}\right), \mathrm{HRP}$ converts a substrate into a chromogenic product which, then, can be detected by light microscopy. Although IHC is a powerful detection method, the use of natural enzymes has some limitations. False-negative staining takes place as a result of the lack of an optimal standard fixation time for each antigen, while compromised HRP sensitivity occurs due to the presence of microorganisms and antibacterial agents. ${ }^{29}$ As such,

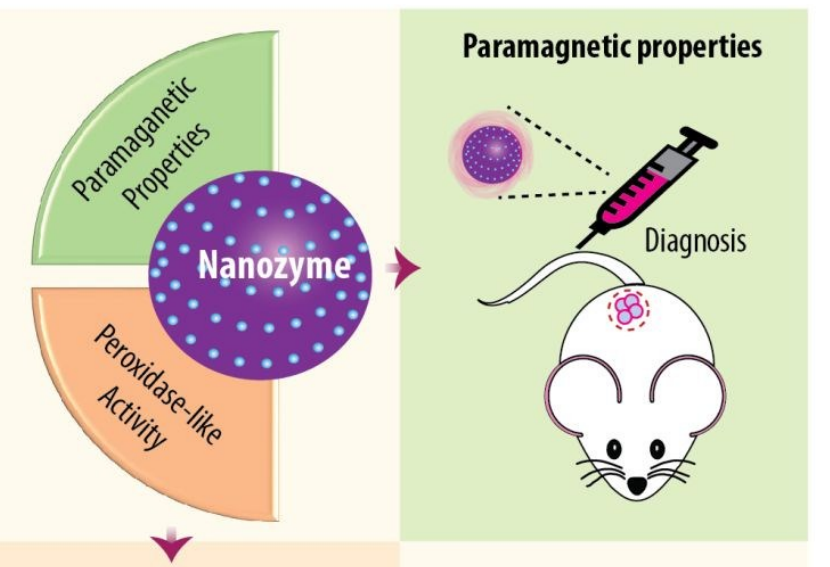

Peroxidase-like activity

Cell-level effect

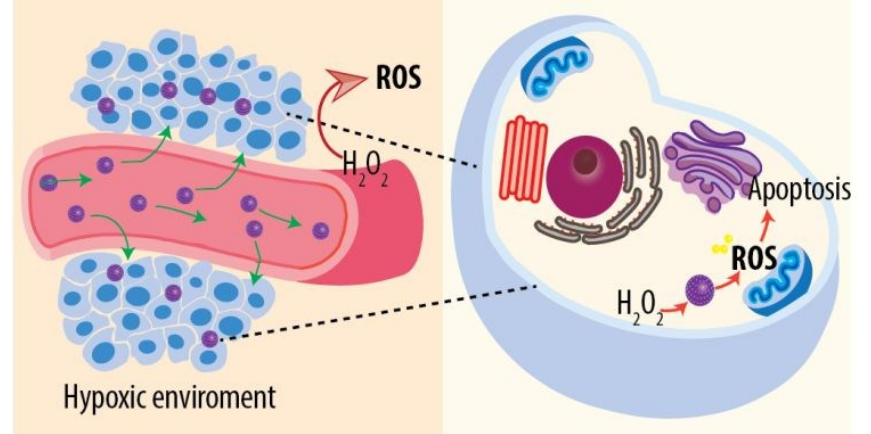

Scheme 1. Schematic illustration of nanozymes based on iron oxide $\left(\mathrm{Fe}_{3} \mathrm{O}_{4}\right)$ nanoparticles $\left(\mathrm{Fe}_{3} \mathrm{O}_{4}\right.$-NPs). The nanozymes combine both enzymatic-like activity (e.g., peroxidase) and unique intrinsic properties of nanomaterials (e.g., paramagnetic properties). While their paramagnetic properties make $\mathrm{Fe}_{3} \mathrm{O}_{4}-\mathrm{NPs}$ very suitable for imaging applications, the $\mathrm{Fe}_{3} \mathrm{O}_{4}$-NPs peroxidase-like activity was used for the generation of toxic reactive oxygen species (ROS) resulting from hydrogen peroxide $\left(\mathrm{H}_{2} \mathrm{O}_{2}\right)$ breakdown in hypoxic conditions of the tumour environment. multifunctional nanozymes with peroxidase-like activity have

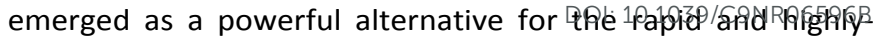
sensitive detection of cancer biomarker molecules. ${ }^{29,38}$

Histochemical visualization by means of multifunctional nanozymes has been mainly conducted employing iron oxide $\left(\mathrm{Fe}_{3} \mathrm{O}_{4}\right)$ nanoparticles (NPs). ${ }^{39}$ While $\mathrm{Fe}_{3} \mathrm{O}_{4}$-NPs have been widely employed as carriers for targeted drug delivery, their enzyme-like properties have been overlooked for a long time and, only recently, their peroxidase-like activity has started to be explored.

One of the first reports, took advantage of both the peroxidase-like activity and magnetic properties of $\mathrm{Fe}_{3} \mathrm{O}_{4}$-NPs in order to assess their bio-distribution, pharmacokinetics and organ clearance in tumour mice models. ${ }^{39}$ The visualization of the $\mathrm{Fe}_{3} \mathrm{O}_{4}$-NPs was first demonstrated by the oxidation of the 3,3,5,5-tetramethylbenzydine (TMB) substrate which, in the presence of $\mathrm{H}_{2} \mathrm{O}_{2}$, forms a brown precipitate at the NPs sites. Next, the results were corroborated by the traditional Prussian blue assay and magnetic resonance imaging (MRI) analysis due to the $\mathrm{Fe}_{3} \mathrm{O}_{4}-\mathrm{NPs}$ magnetic properties. The catalytic properties of $\mathrm{Fe}_{3} \mathrm{O}_{4}$-NPs resulted in higher sensitivity when compared to Prussian blue assay. Furthermore, the TMB conversion by the $\mathrm{Fe}_{3} \mathrm{O}_{4}$-NPs provided more detailed information about the NPs distribution and location as compared to in vivo MRI. Additionally, since such a method is free from complex and costly labelling, it offers the possibility to understand the real behaviour of naked $\mathrm{Fe}_{3} \mathrm{O}_{4}$-NPs which will, in turn, have significant implications for their clinical translation.

Multifunctional $\mathrm{Fe}_{3} \mathrm{O}_{4}$-NPs have also been employed for the pathological analysis of tumours. ${ }^{40} \mathrm{Fan}$ and co-workers were able to assess 474 clinical specimens from patients with nine different types of cancer. For that, $\mathrm{Fe}_{3} \mathrm{O}_{4}-\mathrm{NPs}$ were coated by a recombinant human heavy-chain ferritin protein shell, which binds to tumour cells that overexpress transferrin receptor 1 (TfR1). The results demonstrated that the coated $\mathrm{Fe}_{3} \mathrm{O}_{4}$-NPs were able to target TfR1 and, through their peroxidase-like activity, they were able to discern cancer cells from healthy ones with $98 \%$ and $95 \%$ sensitivity and specificity, respectively. Following on, a sophisticated example employing also multifunctional $\mathrm{Fe}_{3} \mathrm{O}_{4}$-NPs for cancer diagnostics was reported by Chen and co-workers. ${ }^{38}$ The authors synthesised a truly multifunctional nanoprobe based on gold $(\mathrm{Au}) / \mathrm{Fe}_{3} \mathrm{O}_{4}$ hybrid NPs conjugated to folic acid (FA), europium III (Eu) complex and fluorescein isothiocyanate (FITC). Such a multimodal detection system was based on fluorescence imaging (FI), colorimetric and fluorigenic detection together with MRI. The goal was to simultaneously detect and count cancer cells overexpressing the folate receptor. ${ }^{38}$ To do so, upon incubation with the NPs, the cells were first analysed by $\mathrm{FI}$ (due to the FITC labelling) followed by T2 MRI due to their magnetic properties. Next, a colorimetric/fluorigenic dualmodal detection was used for the quantification of cancer cells. The cancer cells overexpressing the folate receptor were first quantified by the peroxidase-like properties of the $\mathrm{Au} / \mathrm{Fe}_{3} \mathrm{O}_{4}-\mathrm{NPs}$ which, in the presence of $\mathrm{H}_{2} \mathrm{O}_{2}$, were able to catalyse the conversion of $\mathrm{TMB}$ into a colorimetric product. The results were further confirmed by FI measurements since, 
the conjugated Eu complex, was able to catalyse the conversion of the calcium dipicolinate substrate into a fluorescent adduct. With such a sophisticated multimodal platform the authors were able to detect and quantify cancer cell numbers as low as 100, thus showing potential as a promising tool for the early diagnosis of cancer.

$\mathrm{Au}$ nanoclusters (Au-NCS), which also display intrinsic peroxidase-like activity, have also been evaluated in the context of cancer diagnostics. ${ }^{29}$ In particular, Au-NCs functionalised with FA have been used to visualize tumour tissues exploiting their multiple functionality. The enzymatic activity of the Au-NCs was first used to catalyse the conversion of colorimetric peroxidase substrates followed by microscopic imaging of the tissues. Next, the excellent luminescence properties of the Au-NCs were used to confirm the results by NIR fluorescence imaging. By examining different clinical samples, it was possible to verify that such a nanoprobe displaying both high fluorescence and enzymatic activity could efficiently avoid the false-positive and false-negative results that are usually obtained in the histochemical diagnostic of tumours. It is also important to note that, in contrast to conventional antibody-based IHC methods which involve various manipulation steps, the reported multifunctional nanozymes for cancer diagnostics involve a one-step incubation procedure. This translates in yielding highly accurate and reproducible results.

Due to the tremendous contribution of nanotechnology to anticancer therapies, multifunctional nanozymes able to synergistically combine several properties have also been explored in this context. As such, iron-based $\mathrm{Fe}_{3} \mathrm{O}_{4}-\mathrm{NPs}$ have been widely evaluated in the context of tumour elimination. However, as opposed to the reports for diagnostic purposes, the $\mathrm{Fe}_{3} \mathrm{O}_{4}$-NPs peroxidase-like activity was used for the generation of toxic reactive oxygen species (ROS) resulting from $\mathrm{H}_{2} \mathrm{O}_{2}$ breakdown.

The first in vivo study using HRP-mimicking nanozymes for cancer therapy was reported by Wang et al. who were able to demonstrate the ability of $\mathrm{Fe}_{3} \mathrm{O}_{4}$-NPs in inhibiting tumour growth in mice. ${ }^{41}$ The results showed the best anti-tumour efficacy when $\mathrm{Fe}_{3} \mathrm{O}_{4}$-NPs were injected together with $\mathrm{H}_{2} \mathrm{O}_{2}$ which resulted in nearly $99 \%$ tumour inhibition after 17 days. In contrast to photosensitizers (PS) used in photodynamic therapy (PDT), $\mathrm{Fe}_{3} \mathrm{O}_{4}$-NPs can generate ROS without the need of light irradiation. Additionally, it was also demonstrated that antitumor therapy could be combined with tumour imaging by means of the enhanced T2-weighted signal from $\mathrm{Fe}_{3} \mathrm{O}_{4}$-NPs in $\mathrm{MRI}$, thus highlighting the potential of $\mathrm{Fe}_{3} \mathrm{O}_{4}-\mathrm{NPs}$ for cancer theranostics.

Alternatively, approaches to avoid the administration of $\mathrm{H}_{2} \mathrm{O}_{2}$, which could potentially be toxic for normal tissues, have also been developed. ${ }^{42}$ Shi et al. were able to generate $\mathrm{H}_{2} \mathrm{O}_{2}$ in situ by the oxidation of glucose by the native glucose oxidase (GOx) enzyme. Biological GOx enzyme was administered together with a peroxidase-like nanozyme to create a two-step catalytic nanomedicine for tumour therapy. While GOx catalysed the oxidation of glucose generating $\mathrm{H}_{2} \mathrm{O}_{2}$ as a by-product, $\mathrm{Fe}_{3} \mathrm{O}_{4}$ NPs were able to convert the as-produced $\mathrm{H}_{2} \mathrm{O}_{2}$ into highly toxic hydroxyl radicals. By co-encapsulating GOx and untrialesmall $\mathrm{Fe}_{3} \mathrm{O}_{4}$-NPs within dendritic mesoporous 1 s. authors were able to demonstrate that the generated hydroxyl radicals were able to initiate the apoptosis and death of tumour cells in vitro. The therapeutic potential of the asprepared NPs was also evaluated in 4T1 and U87 tumour xenograft models. Upon intravenous administration, a high tumour-suppression effect toward both types of tumours could be observed. In particular a $64.67 \%$ and a $57.24 \%$ tumour suppression was observed for the 4T1 mammary and the U87 tumour xenograft, respectively. Intra-tumour administration of the NPs was also studied for the 4T1 mammary tumour xenograft which resulted on a $68.89 \%$ suppression effect.

Multifunctional nanozymes have also been evaluated in the context of PDT. PDT is a non-invasive tumour-ablating intervention involving the production of highly cytotoxic ROS. ${ }^{43}$ PDT generally involves the administration of a PS to the tumour site which, following light illumination, is able to convert local oxygen molecules into ROS subsequently triggering cell death. However, the therapeutic efficiency of PDT is severely hampered by tumour hypoxia, which occurs due to the lack of blood supply as a result from the rapid tumour growth. In this context, multifunctional nanozymes able to generate molecular oxygen within the hypoxic regions have been explored as a promising solution for effective PDT in cancer.

One of the first examples to diminish hypoxia at the tumour site employed manganese ferrite NPs $\left(\mathrm{MnFe}_{2} \mathrm{O}_{4}-\mathrm{NPs}\right){ }^{44}$ $\mathrm{MnFe}_{2} \mathrm{O}_{4}$-NPs were chosen due to their ability to catalyse the conversion of $\mathrm{H}_{2} \mathrm{O}_{2}$, which is present in the cancer environment, into molecular oxygen. Chlorine6 (Ce6), which was chosen as the PS to convert oxygen molecules into ROS, was co-encapsulated together with $\mathrm{MnFe}_{2} \mathrm{O}_{4}-\mathrm{NPs}$ within mesoporous silica NPs. The authors were able to demonstrate enhancement of PDT's therapeutic efficiency as a result of continuous ROS production under laser irradiation (Figure 1A). Additionally, the $\mathrm{T} 2$ contrast effect in MRI by the $\mathrm{MnFe}_{2} \mathrm{O}_{4}-\mathrm{NPs}$ was used to track the NPs fate in vivo (Figure 1B).

On a different approach, iron-based nanozymes were evaluated in the context of tumour hypoxia by making use of $\mathrm{Fe}^{3+}$-doped two-dimensional $\mathrm{C}_{3} \mathrm{~N}_{4}$ nanofusiforms $\left(\mathrm{C}_{3} \mathrm{~N}_{4}-\mathrm{NFs}\right) .^{45}$ While two-dimensional nanosheets were chosen due to their ultrahigh surface area which makes it possible to load high amounts of PS, doping with $\mathrm{Fe}^{3+}$ lead to a peroxidase mimetic able to locally catalyse the $\mathrm{H}_{2} \mathrm{O}_{2}$ decomposition into molecular oxygen. $\mathrm{C}_{3} \mathrm{~N}_{4}-\mathrm{NFs}$ were also functionalised for mitochondria targeting. Due to the main role of mitochondria in the intracellular generation of ROS, such a modification increased the sensitivity of cancer cells to PDT. Additionally, in vivo MRI studies showed that $\mathrm{Fe}^{3+}$-doping endowed the system with the ability to serve as an efficient T1-weighted MRI contrast agent. All in all, such $\mathrm{C}_{3} \mathrm{~N}_{4}$-based multifunctional platform combining oxygen generation, mitochondrion targeting and PDT, was able to almost completely destroy a mouse cervical tumour.

In follow up work, the same group employed the $\mathrm{Fe}^{3+}$-doping strategy to functionalise polydiaminopyridine nanofusiforms 

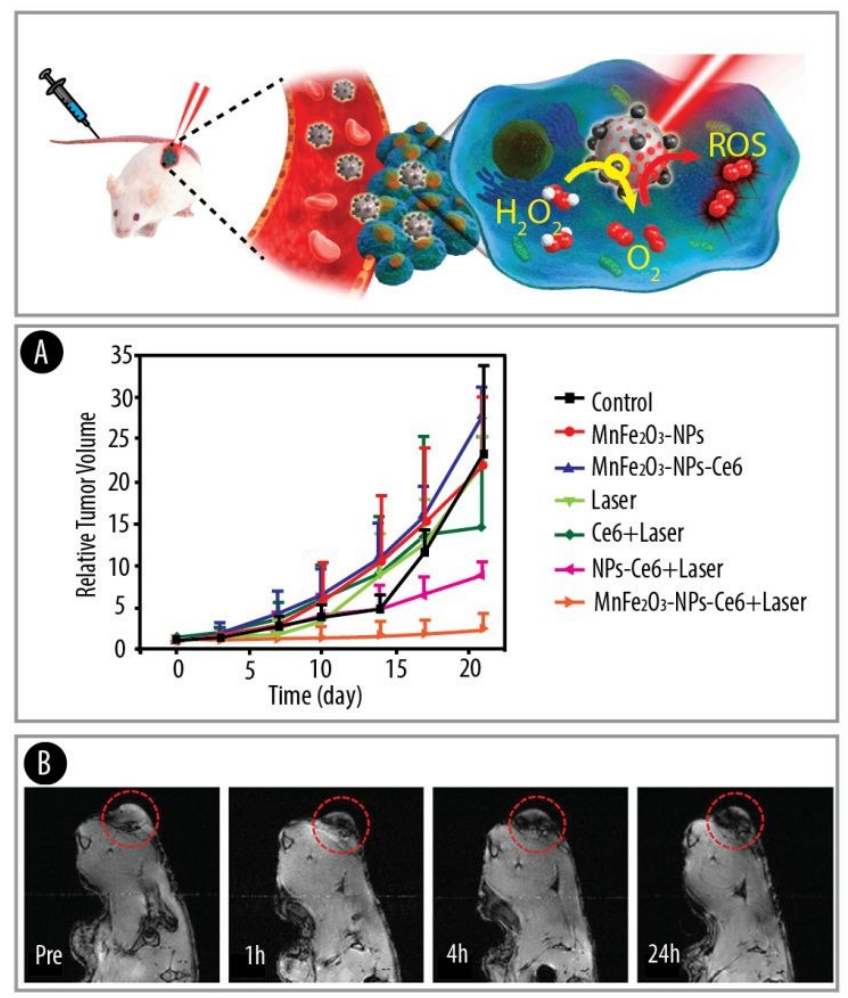

Figure 1. Schematic illustration of photodynamic therapy. A) Tumour volume changes of each group after 3 weeks $(n=3)$. B) In vivo T2* weighted magnetic resonance images of a tumour-bearing mouse at various time periods. Tumours are circled with red dashed lines. Reprinted with permission from [44]. Copyright 2017 American Chemical Society.

(PDAP-NFs). ${ }^{30}$ PDAP-NFs were chosen due to the bipolaronic metal property of doped polymers, ${ }^{46}$ which endorses them with a broad NIR absorption. Such nanoconstructs were able to overcome tumour hypoxia and enhance the efficiency of PDT. Furthermore, they served for MRI but also thermal imaging as a result of the NIR light absorption. In vivo treatment of mice with the PDAP-NFs resulted in enhanced tumour inhibition efficacy when PDT but also photothermal therapy (PTT) due to their NIR absorption properties were used in combination.

Alternatively, also due to their peroxidase-like catalytic properties, Au-based nanomaterials have also been employed in the context of PDT. In a first study conducted by Li et al., a nanoconstruct based on mesoporous core-shell Au-platinum (Pt) NPs (Au@Pt-NPs) was fabricated. ${ }^{47}$ The Au@Pt-NPs were first loaded with Ce6 and their surface functionalized by both cell-targeting (i.e., FA) and mitochondria-targeting ligands. As a result of the ability of $\mathrm{Au}$ to catalyse the conversion of $\mathrm{H}_{2} \mathrm{O}_{2}$ into molecular oxygen, such a system was able to significantly improve the PDT efficacy. Furthermore, the as-prepared Au@Pt-NPs were able to convert laser radiation into heat, thus provoking thermally induced tumour cell damage. Therefore, by combining PDT and PTT, such a nanoconstruct could be employed as a dual-mode therapeutic agent for improved cancer therapy.

Another recent example making use of Au-based nanozymes, employed individual AuNPs coated by a porous hollow carbon nanospheres (HCN) rendering Au@HCN-NPs. ${ }^{48}$ veue Putite $_{\text {the }}$

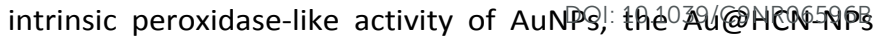
demonstrated the ability to catalyse the $\mathrm{H}_{2} \mathrm{O}_{2}$ decomposition into highly toxic ROS. Tumour PDT was combined with PTT since both carbon-based materials ${ }^{49-51}$ and $\mathrm{Au}-\mathrm{NPs}^{52,53}$ have the ability to absorb NIR light transforming it into heat. The results demonstrated a synergized effect on tumour treatment by the combination of the production of highly toxic ROS and PTT both in cellular and animal studies with mice models.

\subsection{Antioxidant activity}

Within our organism, ROS such as $\mathrm{H}_{2} \mathrm{O}_{2}$, superoxide $\left(\mathrm{O}_{2}{ }^{--}\right)$and hydroxyl $\left({ }^{\circ} \mathrm{OH}\right)$ radicals, which are continuously produced as by-products of the oxygen metabolism, ${ }^{54}$ are responsible for important tasks such as cell signalling, homeostasis or pathogen defence. ${ }^{55}$ However, high levels of ROS also promote protein denaturation, lipid peroxidation or DNA damage thus provoking adverse effects on cells. ${ }^{56}$ To preserve the intracellular redox balance and protect our organism from oxidative stress, antioxidant enzymes such as superoxide dismutase (SOD), catalase (CAT) or glutathione peroxidase (GPx) work together to create an intracellular antioxidant defence system. ${ }^{57}$

However, such antioxidant enzymes may be insufficient to protect cells from sudden oxidative stress which is closely related to the development of many metabolic diseases including type 2 diabetes, ${ }^{58,59}$ neurodegenerative diseases, such as Parkinson's (PD) and Alzheimer's disease (AD) $)^{60,61}$ or inflammations and cancers. ${ }^{62}$ To this end, multifunctional nanozymes able to mimic our intracellular enzyme-based defence system have emerged a promising therapeutic solution.

A first example was reported by Xiong and co-workers by making use of multifunctional Au-platinum (Pt) nanocomposites (Au@Pt-NCs). ${ }^{63}$ The antioxidant properties of the Au@Pt-NCs were employed to prevent sudden oxidative damage of human skin cells caused by ultraviolet (UV) light. This is an important biomedical issue since, the increasing air pollution and reduction of the ozone layer in recent years, have resulted in UV irradiation-caused damage. ${ }^{64}$ Such UVinduced cell impairment occurs as a result of excessive ROS production. As such, Xiong et al. made use of the high catalytic activity of the Au@Pt-NCs for cellular ROS scavenging. The Au@Pt-NCs were fabricated by growing a Pt coating on the surface of Au nanorods which were used as seeds. Next, the catalytic activity of the nanozymes was assessed in terms of their ability to deplete $\mathrm{O}_{2}{ }^{--}$and $\mathrm{H}_{2} \mathrm{O}_{2}$ employing colorimetric assays commonly used to assess SOD and CAT activities. Interestingly, the results demonstrated a notably higher catalytic activity for the Au@Pt-NCs as compared to bare Au nanorods or Pt-NPs. The antioxidant ability was also assessed on a human keratinocytes model system (HaCaT cells) since keratinocytes are the cells of the most outer layer of the skin which is the most affected upon UV light irradiation. The authors were able to demonstrate the protection offered by Au@Pt-NCs towards UV-induced ROS stress. Cells treated with 
Au@Pt-NCs showed the lowest ROS levels and highest cell viability and proliferation readings.

On a different study, the antioxidant abilities of Pt-containing nanozymes were also evaluated but this time in combination with palladium (Pd). ${ }^{65}$ Shibuya et al. chose a mixture of $\mathrm{Pd}$ - and Pt-NPs which has been used in Japan for over 60 years for the treatment of chronic diseases (the so called PAPLAL, Toyokose Pharmaceuticals, Japan). The authors evaluated the antioxidant effects of transdermal PAPLAL treatment against aging-related skin pathologies in SOD-deficient mice. The SODdeficient mice were chosen since, several aging-related phenotypes including skin atrophy, are a result of the $\mathrm{O}_{2}{ }^{-}$ excess which takes place upon SOD loss over the years within our organism. ${ }^{65}$ The beneficial effects of PAPLAL were first evaluated in Sod1 ${ }^{-/-}$fibroblast culture demonstrating a markedly higher outgrowth capacity upon PAPLAL treatment. Next, the skin atrophy as a result of SOD deficiency of Sod1-1mice was verified by their significantly thinner skin as compared to Sod $1^{+/+}$mice. The results following transdermal administration of PAPLAL in mice showed a significant increase of the back skin thickness (of about $46.2 \%$ and $19.2 \%$ in epidermis and dermis, respectively) as compared to the untreated mice. Expression profile analysis of skin-related genes, including those involved in matrix biosynthesis, inflammation and aging, showed how PAPLAL treatment markedly normalized the mRNA expression of genes related to the production of ECMs components (e.g., collagen or hyaluronic acid).

A last study involving Pt-based multifunctional nanozymes was conducted in the context of brain injury. ${ }^{66} \mathrm{~A}$ trimetallic nanozyme (triM) consisting of a combination of $\mathrm{Pt}, \mathrm{Pd}$ and molybdenum oxide was prepared. While Pt and Pd were chosen due to their well-documented antioxidant catalytic activity, ${ }^{14,67,68}$ molybdenum dopants have been reported to enhance the stability of Pt-based nanozymes. ${ }^{69}$ It was demonstrated that such a triM system displayed multipleenzyme mimetic activities since triMs were able to remove

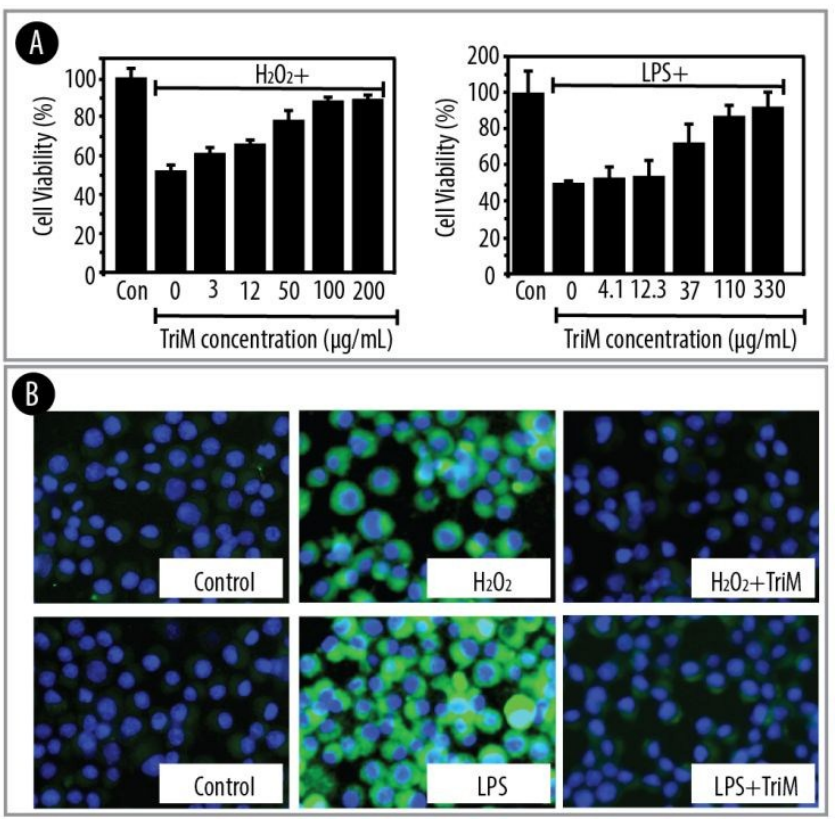

Figure 2. In vitro treatment of triM nanozymes. A) Cell viability measurement of (left) $\mathrm{H}_{2} \mathrm{O}_{2}$ - or (right) lipopolysaccharide (LPS)-treated $\mathrm{N} 2$ a cells in the presence of

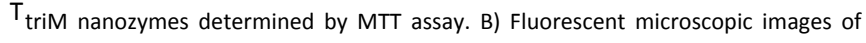
intracellular ROS levels under different conditions. Blue, cell nuclei stained by Hoechst 33342 dye; green, Dichlorodihydrofluorescein (DCF) yielded by ROS oxidizing nonfluorescent DCFH. Reprinted with permission form [66]. Copyright 2019 American Chemical Society.
ROS such as $\mathrm{O}_{2}{ }^{-}, \mathrm{H}_{2} \mathrm{O}_{2}$ and $\cdot \mathrm{OH}$, but also reactive ${ }_{\mathrm{A}}$ nitregen

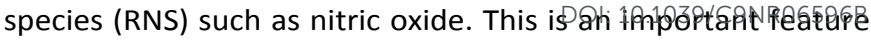
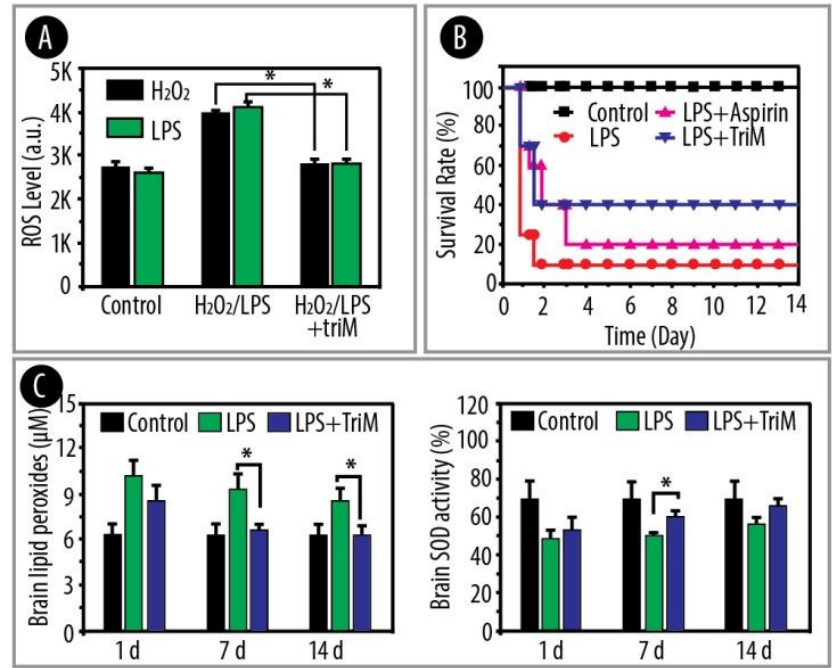

Figure 3. A) Quantitative analysis of intracellular ROS level with the TriM nanozyme treatment in $\mathrm{H}_{2} \mathrm{O}_{2}$ - or LPS-stimulated $\mathrm{N} 2 \mathrm{a}$ cells as determined by flow cytometry using a DCFH-DA dye. ${ }^{*}$ indicates $\mathrm{p}<0.05$ as compared with the $\mathrm{H}_{2} \mathrm{O}_{2}$ - or LPS-treated group (Student's test). B) Survival curves of mice with or without treatment with trim nanozymes observed for 14 days; $n=20$. Aspirin was adopted as positive control. C) Lipid peroxides (left) and SOD activity (right) assays in the brain at 1, 7 and 14 days. All results were obtained from three groups: healthy control, LPS injection only and LPS+triM injection. * indicates $p<0.05$ as compared to the control group (Student's test). Reprinted with permission form [66]. Copyright 2019 American Chemical Society

since brain injury involves different kinds of ROS but also RNS. In order to assess the potential of triM on a cellular level, the in vitro experiments employing both an $\mathrm{H}_{2} \mathrm{O}_{2-}$ and a LPSinduced injured neural cells, demonstrated how triM treatment resulted on a marked recovery in both SOD activity and lipid peroxidation. This, enhanced recovery translated into an increase of the viability of the injured neural cells (Figure 2A). A decrease on the ROS levels as determined by fluorescence microscopy images (Figure 2B) and flow cytometry (Figure 3 A) could also be observed. In addition, the in vivo evaluation employing a brain injury murine model demonstrated how triM treatment resulted on a marked improvement of the survival rate (Figure $3 \mathrm{~B}$ ), neuroinflamation (Figure $3 C$ ) and reference memory of injured mice.

Alternatively, iron-based multifunctional nanozymes, due to their peroxidase- and catalase-like activities, have also been employed for antioxidant therapy. ${ }^{18,70}$ As a first example, $\mathrm{Fe}_{2} \mathrm{O}_{3}$-NPs were evaluated in the context of cardioprotection from ischemic impairment. ${ }^{70}$ This is an important biomedical application since, myocardial ischemia resulting from the lack of blood flow into the heart, is the main responsible for myocardium damage which can then translate, amongst others, into myocardial infarction. For this application, $\mathrm{Fe}_{2} \mathrm{O}_{3}-$ NPs modified by 2,3-dimercaptosuccinic acid were assessed in terms of their cardioprotective properties both in vitro and in vivo. To assess the $\mathrm{Fe}_{2} \mathrm{O}_{3}$-NPs potential at a cellular level, neonatal rat cardiomyocytes exposed to ischemia and reperfusion were employed. The results showed an increase in both cell viability and SOD activity for the treatment groups 
(Figure 4A). Furthermore, decreased ROS content was observed following $\mathrm{Fe}_{2} \mathrm{O}_{3}$-NPs administration (Figure 4A). The cardioprotection was also evaluated on Guinea pig Langendorff hearts, which are widely employed to evaluate cardiovascular drugs at a tissue level. The perfused hearts, which had been previously exposed to ischemia and reperfusion, exhibited marked recovery on the left ventricular developed pressure (LVDP) for the $\mathrm{Fe}_{2} \mathrm{O}_{3}$-NPs-treated group (Figure 4B). The in vivo evaluation was conducted in SpragueDawley rats following injury by coronary artery ligature. The results showed how treatment with $\mathrm{Fe}_{2} \mathrm{O}_{3}$-NPs resulted on infarct regions markedly smaller than the control group. Finally, investigation of biochemical indexes, revealed a significantly higher SOD activity of the $\mathrm{Fe}_{2} \mathrm{O}_{3}$-NPs treated rats as compared to the saline-treated group, thus demonstrating the antioxidant properties of the $\mathrm{Fe}_{2} \mathrm{O}_{3}$-NPs.

The antioxidant properties of $\mathrm{Fe}_{3} \mathrm{O}_{4}$-NPs have also been explored in the context of neurodegenerative diseases. ${ }^{18}$ The biological effects of $\mathrm{Fe}_{3} \mathrm{O}_{4}$-NPs were first evaluated in vitro in the context of PD. Differentiated PC12 cells, which are a neuron-like cell model widely employed as a PD's cell model, ${ }^{71-73}$ were treated with 1-methyl-4-phenylpyridinium ion $\left(\mathrm{MPP}^{+}\right)$to induce oxidative stress and apoptosis. Preincubation with $\mathrm{Fe}_{3} \mathrm{O}_{4}$-NPs significantly reduced the ROS levels while also enhancing the viability of the cells. The effects of $\mathrm{Fe}_{3} \mathrm{O}_{4}$-NPs were next evaluated in vivo this time using an $A D$ Drosophila model. ${ }^{18}$ The authors employed an ectopic expression of beta-amyloid $(A \beta)$ or its precursor in Drosophila as the in vivo model since, the first pathological step of $A D$, is the accumulation of $A \beta$ peptides. ${ }^{60,74}$

The authors were also able to demonstrate a decrease in the ROS levels, $A \beta$ accumulation and a prolonged life span for flies following dietary ingestion of the $\mathrm{Fe}_{3} \mathrm{O}_{4}$-NPs.

\subsection{Antibacterial activity}

Infectious diseases caused by bacteria are a major public safety issue currently leading to millions of deaths every year. ${ }^{75}$ Persistent bacterial infections are associated with the formation of biofilms, which are multicellular communities embedded within a self-produced extracellular polymeric substances (EPS). ${ }^{76,77}$ Bacterial biofilms are often associated with persistent infections and even death ${ }^{78}$ since, bacteria enclosed within these protecting biofilms, are extremely resistant to ordinary antibiotics and host immune defences. ${ }^{79-}$ 81 Therefore, combating biofilms remains as an enormous medical challenge.

Recently, nanoparticulate materials have emerged as potential antimicrobial agents. ${ }^{82-86}$ Antimicrobial NPs, including nanozymes, display unique advantages since they can target a wide range of different bacteria by different biological pathways. Such antimicrobial approaches include compromising the bacterial cell membrane, ROS production to damage cell components or the inhibition of enzyme activity and DNA synthesis. ${ }^{87}$

So far, the most employed approach by multifunctional nanozymes with antibacterial properties is the conversion of $\mathrm{H}_{2} \mathrm{O}_{2}$ into free radicals. ${ }^{41,88-90}$ While $\mathrm{H}_{2} \mathrm{O}_{2}$ is currently widely used as an antibacterial agent for hygienic and $\mathrm{d}_{\mathrm{Ar}}$ medical

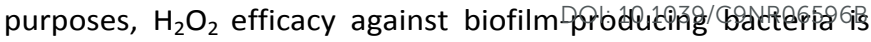
quite limited due to its poor penetration into the EPS matrix. ${ }^{88}$ Thus, $\mathrm{Fe}_{3} \mathrm{O}_{4}$-NPs with the ability to catalyse the conversion of
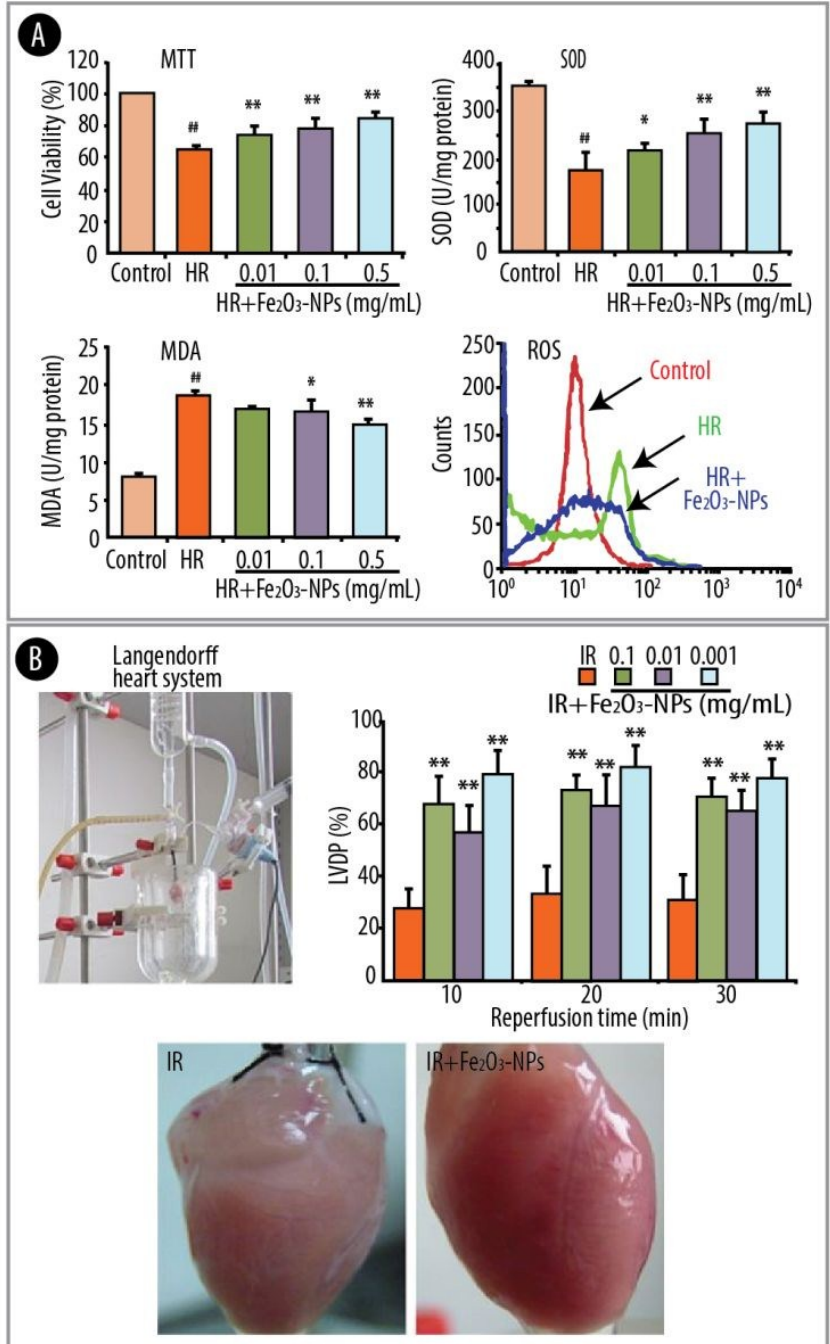

Figure 4. A) Effects of $\mathrm{Fe}_{2} \mathrm{O}_{3}$-NPs on cardiomyocytes under a hypoxia $\left(95 \% \mathrm{~N}_{2}\right.$ and $5 \%$ $\left.\mathrm{CO}_{2}\right)(6 \mathrm{~h})$ and reoxygenation $\left(95 \% \mathrm{O}_{2}\right.$ and $\left.5 \% \mathrm{CO}_{2}\right)(6 \mathrm{~h})(\mathrm{HR})$ condition, including effects of $\mathrm{Fe}_{2} \mathrm{O}_{3}$-NPs on cell viability, generation of SOD, MDA and ROS. ${ }^{*} \mathrm{p}<0.05$ vs the HR group; ${ }^{* *} \mathrm{p}<0.01$ vs the HR group; \#\# $\mathrm{p}<0.01$ vs the control group; $\mathrm{n}=6$. B) Caridoprotective activity of $\mathrm{Fe}_{2} \mathrm{O}_{3}$-NPs on guinea pig Langendorff heart following $30 \mathrm{~min}$ of ischemia and $30 \mathrm{~min}$ of reperfusion (IR). Images of the Langendorff heart system, a heart perfused without (IR) and with $0.001 \mathrm{mg} / \mathrm{ml}$ of $\mathrm{Fe}_{2} \mathrm{O}_{3}-\mathrm{NPs}(\mathrm{IR}+$ $\mathrm{Fe}_{2} \mathrm{O}_{3}$-NPs) after ischemia and left ventricular developed pressure (LVDP) recording with perfused hearts without and with $0.1,0.01$ and $0.001 \mathrm{mg} / \mathrm{ml}$ of $\mathrm{Fe}_{2} \mathrm{O}_{3}-\mathrm{NPs}$ at 10,20 and $30 \mathrm{~min}$ after perfusion. ${ }^{* *} \mathrm{p}<0.01$ vs the IR group; $\mathrm{n}=6$. Reprinted with permission from [70]. Nature Scientific reports open access.

$\mathrm{H}_{2} \mathrm{O}_{2}$ into free radicals have emerged as promising antibacterial agents. ${ }^{41,88,91}$

In a first study, $\mathrm{Fe}_{3} \mathrm{O}_{4}$-NPs were evaluated in the context of biofilm degradation by means of their ability to degrade model biofilm components such as nucleic acids, proteins and polysaccharides. ${ }^{88} \mathrm{Fe}_{3} \mathrm{O}_{4}$-NPs in the presence of $\mathrm{H}_{2} \mathrm{O}_{2}$ at concentrations consistent with domestic hygiene uses (of 1-3\% in water) were incubated with different samples of DNA and proteins such as bovine serum albumin or chitosan. The results, as shown by SDS-PAGE, showed an enhanced or even 
complete cleavage for samples following treatment with both $\mathrm{Fe}_{3} \mathrm{O}_{4}$-NPs and $\mathrm{H}_{2} \mathrm{O}_{2}$. The mechanism, which was assessed employing an ${ }^{\circ} \mathrm{OH}$ scavenger (hypotaurine), demonstrated that the enhanced cleavage of the different biomolecules was reliant on the free $\cdot \mathrm{OH}$ resulting from the peroxidase-like activity of the $\mathrm{Fe}_{3} \mathrm{O}_{4}$-NPs. The antibacterial properties, which were further evaluated within live biofilms, showed the $\mathrm{Fe}_{3} \mathrm{O}_{4}$ NPs ability to penetrate and degrade the biofilm created by Pseudomonas aeruginosa, which is responsible of resistant nosocomial infection. By quantifying the number of colony forming units (CFUs) it was possible to demonstrate degradation of $\sim 94 \%$ of the biofilm following treatment with both $\mathrm{Fe}_{3} \mathrm{O}_{4}-\mathrm{NPs}$ and $\mathrm{H}_{2} \mathrm{O}_{2}$.

The antibacterial abilities of $\mathrm{Fe}_{3} \mathrm{O}_{4}$-NPs were also explored in combination with MRI. ${ }^{41} \mathrm{Fe}_{3} \mathrm{O}_{4}$-NPs were employed as a highly sensitive MRI contrast agent for tumour targeting and their ability to catalyse the breakdown of $\mathrm{H}_{2} \mathrm{O}_{2}$ into free radicals was evaluated in terms of inhibition of both tumour and bacterial growth. While the anti-tumour properties of the as-prepared $\mathrm{Fe}_{3} \mathrm{O}_{4}$-NPs have been explained in detail in section 2.2; the antibacterial potential of the NPs was assessed using Escherichia coli (E. coli) as a model bacterium. E. coli were incubated with both $\mathrm{Fe}_{3} \mathrm{O}_{4}$-NPs and $\mathrm{H}_{2} \mathrm{O}_{2}$ and the efficacy of the treatment in terms of inhibition of bacterial proliferation was assessed by monitoring the optical density of the suspension at $600 \mathrm{~nm}$. The results demonstrated complete inhibition for $E$. coli incubated with both $\mathrm{Fe}_{3} \mathrm{O}_{4}-\mathrm{NPs}$ and $\mathrm{H}_{2} \mathrm{O}_{2}$ after $24 \mathrm{~h}$ for the three studied $\mathrm{pH}$ values $(\mathrm{pH}=5.5,6.8$ and 7.4). Transmission electron microscopy (TEM) images show complete destruction of the bacteria following treatment with both $\mathrm{Fe}_{3} \mathrm{O}_{4}-\mathrm{NPs}$ and $\mathrm{H}_{2} \mathrm{O}_{2}$ for only $1 \mathrm{~h}$. In contrast, the cell integrity of $E$. coli treated with $\mathrm{Fe}_{3} \mathrm{O}_{4}-\mathrm{NPs}$ or $\mathrm{H}_{2} \mathrm{O}_{2}$ alone was not compromised as shown by TEM images. The $E$. coli death was further confirmed by propidium iodide staining.

The antibacterial potential of $\mathrm{Fe}_{3} \mathrm{O}_{4}$-NPs was further evaluated in the context of dental biofilms, which are also known as plaque. ${ }^{89}$ Dental caries (tooth decay) is one of the most prevailing and costly biofilm-associated oral diseases. ${ }^{92-94}$ Dental biofilms develop when bacteria such as Streptococcus mutans (S. mutans) make use of dietary carbohydrates to generate EPS which accumulate onto the teeth surface..$^{92,93}$ Bacteria entrapped within this EPS-rich matrix persist while generating niches with acidic $\mathrm{pH}(\mathrm{pH} \sim 4.5)$ which are then responsible for teeth erosion and the subsequent dental caries. ${ }^{92-94}$ Within this study, the potential of $\mathrm{Fe}_{3} \mathrm{O}_{4}-\mathrm{NPs}$ to degrade the extracellular matrix and to deplete bacteria at highly acidic conditions was assessed. To mimic the pathogenic situation, S. mutans-based biofilms were formed in the presence of sucrose on saliva-coated hydroxyapatite surfaces. Next, the ability of $\mathrm{Fe}_{3} \mathrm{O}_{4}$-NPs to catalyse $\mathrm{H}_{2} \mathrm{O}_{2}$ 's breakdown in acidic conditions was demonstrated by the colorimetric TMB method (Figure 5A).${ }^{91}$ Following on, the bactericidal properties of the NPs were evaluated by assessing both the number of viable cells as well as the EPS content following incubation for 5 min (Figure 5B). The results, which show $\sim 99.9 \%$ cell depletion upon treatment with both $\mathrm{Fe}_{3} \mathrm{O}_{4}-\mathrm{NPs}$ and $\mathrm{H}_{2} \mathrm{O}_{2}$, suggest a synergistic effect between the two components enhancing their killing efficacy. Further analysis sevealed lina marked decrease in both soluble and insoplible ${ }^{1}$ epss qexpeessea in $\mu \mathrm{g}$ ) upon treatment with the combination of $\mathrm{Fe}_{3} \mathrm{O}_{4}$-NPs and $\mathrm{H}_{2} \mathrm{O}_{2}$ (Figure $5 \mathrm{~B}$ ). In vivo experiments were also conducted using a rodent model of the disease. ${ }^{95}$ Within this murine model, teeth increasingly develop carious lesions starting with

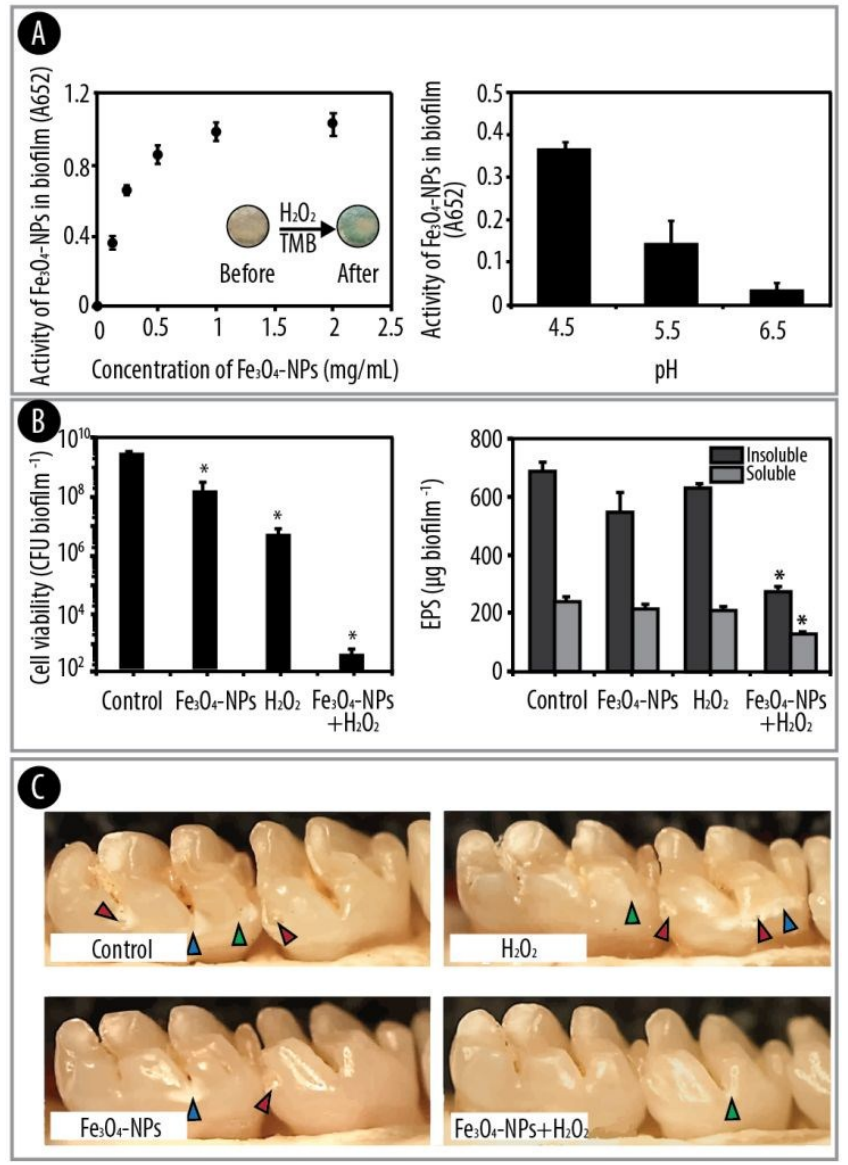

Figure 5. A) $\mathrm{Fe}_{3} \mathrm{O}_{4}-\mathrm{NPs}$ activity within biofilms with $\mathrm{pH}$ dependent catalysis in situ. Catalytic activity of $\mathrm{Fe}_{3} \mathrm{O}_{4}$-NPs adsorbed within biofilms. Inset: photographic images of CAT-NP treated biofilm before and after exposure to $\mathrm{H}_{2} \mathrm{O}_{2}$ and $3,3^{\prime} 5,5^{\prime}$ tetramethylbenzidine (TMB) (the blue color indicates free-radical generation via $\mathrm{H}_{2} \mathrm{O}_{2}$ catalysis in situ) (left). Catalytic activity of $\mathrm{Fe}_{3} \mathrm{O}_{4}-\mathrm{NPs}\left(0.5 \mathrm{mg} \mathrm{ml}^{-1}\right)$ treated biofilms at different $\mathrm{pH}$ (right). B) Bacterial killing, EPS degradation by the combination of $\mathrm{Fe}_{3} \mathrm{O}_{4}$-NPs and $\mathrm{H}_{2} \mathrm{O}_{2}$. (left) Viability of $\mathrm{S}$. mutans within $\mathrm{Fe}_{3} \mathrm{O}_{4}$ - $\mathrm{NPs}$ treated-biofilms 5 min after $\mathrm{H}_{2} \mathrm{O}_{2}$ exposure, and (right) EPS degradation within biofilm 30 min after $\mathrm{H}_{2} \mathrm{O}_{2}$ exposure. Data are shown as mean \pm s.d. ${ }^{*} \mathrm{P} \leq 0.001$ (vs. control) C) Protection against development of carious lesions by $\mathrm{Fe}_{3} \mathrm{O}_{4}-\mathrm{NPs} / \mathrm{H}_{2} \mathrm{O}_{2}$ treatment. Images of teeth from rats treated as noted. Green arrows indicate initial lesion formation where areas of the enamel is demineralized and become white; blue arrows show moderate carious lesions where areas of enamel are whiteopaque or damaged. In some areas, the enamel is eroded leading to cavitation, which are the most severe carious lesions (red arrows). Reprinted with permission from [89]. Copy right 2016 Elsevier B.V.

initial enamel demineralization (Figure 5B, green arrow) to further destruction (blue arrows) and finally leading to severe cavitation lesions (red arrow). The results show how, following treatment with the combination of $\mathrm{Fe}_{3} \mathrm{O}_{4}-\mathrm{NPs}$ and $\mathrm{H}_{2} \mathrm{O}_{2}$ for 21 days, resulted on a marked decrease on the initiation and severity of the lesions.

Further research highlighting the antibacterial properties of $\mathrm{Fe}_{3} \mathrm{O}_{4}$-NPs was conducted in the context of subcutaneous 
ulcers..$^{90}$ In this study, a novel composite system consisting of $\mathrm{Fe}_{3} \mathrm{O}_{4}$-NPs and reduced graphene oxide ( $\mathrm{rGO}$ ) was evaluated in a murine model with subcutaneous abscesses. Such a composite system was chosen to achieve a combined treatment making use of rGO's ability to absorb NIR energy together with the peroxidase-like activity of $\mathrm{Fe}_{3} \mathrm{O}_{4}$-NPs. The authors employed a highly sensitive chemiluminescent probe

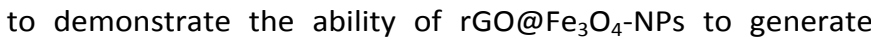
large amounts of ${ }^{\bullet} \mathrm{OH}$ from $\mathrm{H}_{2} \mathrm{O}_{2}$. Importantly, the amount of generated ${ }^{\circ} \mathrm{OH}$ was substantially increased upon NIR laser irradiation. These results suggest that $\mathrm{rGO}$ photothermal effect has an influence on the catalytic activity of $\mathrm{Fe}_{3} \mathrm{O}_{4}$-NPs. The ability to generate ${ }^{\circ} \mathrm{OH}$ radicals was also evaluated in terms of the bactericidal effect both in vitro and in vivo. The in vitro potential of the $\mathrm{rGO} @ \mathrm{Fe}_{3} \mathrm{O}_{4}$-NPs was assessed employing methicillin-resistant Staphylococcus aureus (MRSA) suspensions. Such a bacterial strain was chosen due to the serious challenge that multiple-drug-resistant strains represent to human health. ${ }^{96,97}$ The results demonstrated in vitro inactivation of MRSA following treatment with $\mathrm{rGO} @ \mathrm{Fe}_{3} \mathrm{O}_{4}-$ NPs and exposure to NIR laser. The in vivo experiments were conducted in a mouse model with MRSA-infected subcutaneous abscesses. By evaluating the CFUs obtained from the retrieved abscesses after one day of treatment, it was demonstrated a $\sim 80 \%$ reduction for mice treated with rGO- $\mathrm{Fe}_{3} \mathrm{O}_{4}$-NPs together with NIR irradiation. It is also worth mentioning that neither the in vitro or the in vivo experiments relied on the addition of exogenous $\mathrm{H}_{2} \mathrm{O}_{2}$, thus indicating, in agreement with other reports, ${ }^{98,99}$ a high increase in $\mathrm{H}_{2} \mathrm{O}_{2}$ concentration at the inflammation sites.

Finally, the potential of $\mathrm{Fe}_{3} \mathrm{O}_{4}$-NPs to suppress bacteria intracellularly has also been evaluated. ${ }^{100} \quad \mathrm{Fe}_{3} \mathrm{O}_{4}$-NPs were evaluated in Salmonella enteritidis ( $S$. enteritidis) since Salmonella is one of the major foodborne pathogens. $\mathrm{Fe}_{3} \mathrm{O}_{4-}$ NPs demonstrated the ability to inhibit intracellular $S$. enteritidis survival both in vitro and in vivo. Since it has been previously reported that authophagy is the mechanism used by several cell culture models to protect themselves from Salmonella infection, the authors speculated that $\mathrm{Fe}_{3} \mathrm{O}_{4}$-NPs could advance the authophagy-mediated depletion of $S$. enteritidis by means of their peroxidase-like activity. That is, through ROS generation. The antibacterial effects of $\mathrm{Fe}_{3} \mathrm{O}_{4}-\mathrm{NPS}$ were assessed in $S$. enteritidis-infected Leghorn male hepatoma cells and specific pathogen free chicks. The authors were able to demonstrate that the $\mathrm{Fe}_{3} \mathrm{O}_{4}-\mathrm{NPs}$ could significantly inhibit the growth of $\mathrm{S}$. enteritidis. Furthermore, following oral administration, $\mathrm{Fe}_{3} \mathrm{O}_{4}$-NPs could prevent the $S$. enteritidis invasion of the liver and pathological lesions in the infected chicks.

Antibacterial activity by ROS generation has also been reported making use of nanozymes different than $\mathrm{Fe}_{3} \mathrm{O}_{4-}$ NPs. ${ }^{75,87,101} \mathrm{Au}$-tellurium (Au@Te-NSs), silver (Ag)-tellurium (Ag@Te-NSs), and Au/Ag-tellurium (Au/Ag@Te-NSs) nanostructures were first assessed by their ability to act as HRP-mimics. ${ }^{87}$ The conversion of Amplex Red into the fluorescent resorufin product while generating ROS as byproducts demonstrated higher catalytic activity for the
Au/Ag@Te-NSs as compared to Au@Te-NSs and Ag@iTe-NSS These results also translated into greatepantimincolopalpactivity for Au/Ag@Te-NSs for the three studied bacterial strains (namely, E. coli, Salmonella enterica serovar Enteritidis, and $S$. aureus). The different Te-based NSs were also evaluated in the context of wound dressing materials and inhibition zone measurements were conducted. The results demonstrated larger inhibition zones for $E$. coli for konjac jelly films loaded with Au/Ag@Te-NSs as compared to films loaded with Au@TeNSs or Ag@Te-NSs. The authors attribute the antibacterial effects to the release of $\mathrm{Ag}^{+}$and Te-related ions which, together with ROS generation, could contribute to destroy the bacterial cell membrane.

Pt-based nanozymes have also reported antimicrobial activity by means of ROS generation. ${ }^{101}$ In particular, porous Pt@AgNPs were reported to exert bactericidal effects onto both gram-negative E. coli and gram-positive S. aureus. The Pt@AgNPs displayed both peroxidase-like and catalase-like activities. As such, Pt@Ag-NPs were able both to catalyse the oxidation of the chromogenic TMB substrate and the disproportionation of $\mathrm{H}_{2} \mathrm{O}_{2}$ into water and oxygen. The bactericidal effects of Pt@Ag-NPs which were assessed by recording the absorption of the suspensions, showed that Pt@Ag-NPs alone were able to inhibit about one half of the growth of the two model bacteria. However, when $\mathrm{H}_{2} \mathrm{O}_{2}$ was added ( 10 and $200 \mu \mathrm{M}$ for E. coli and $S$. aureus, respectively) in combination with the Pt@Ag-NPs, the bacterial growth was nearly suppressed for the two studied strains. The integrity of the bacterial cell membrane was also evaluated conducting a lactate dehydrogenase (LDH) assay since, intracellular contents including LDH, would be released if the bacterial cell membrane was broken. The LDH release together with quantification of the intracellular levels of lipid peroxidation indicated damage on the bacterial cell membrane following Pt@Ag-NPs and $\mathrm{H}_{2} \mathrm{O}_{2}$ treatment.

Another approach for bactericidal nanozymes was based on the combination of ultrathin graphitic carbon nitride $\left(g-\mathrm{C}_{3} \mathrm{~N}_{4}\right)$ and Au-NPs. ${ }^{75}$ While the g- $\mathrm{C}_{3} \mathrm{~N}_{4}$ component was chosen due to its antibacterial properties resulting from their ability to catalyse the breakdown of physiological $\mathrm{H}_{2} \mathrm{O}_{2}$ into highly toxic - $\mathrm{OH}$ radicals; Au-NPs were selected to enhance the catalytic activity of enzyme-mimics as a result of their ability to stabilize the free radicals. ${ }^{102-107}$ Although the peroxidase-like activity of $\mathrm{g}^{-} \mathrm{C}_{3} \mathrm{~N}_{4}$ nanosheets has been recently reported, ${ }^{108}$ it is still challenging to achieve a high catalytic efficiency. Thus, g$\mathrm{C}_{3} \mathrm{~N}_{4} @$ @u-NPs nanocomposites were fabricated and their bactericidal properties were evaluated for drug-resistant gram-negative (E. coli) and gram-positive (S. aureus) bacteria. While bare g- $\mathrm{C}_{3} \mathrm{~N}_{4} @ A$ Au-NPs resulted in negligible antibacterial effect as shown by optical density measurements, a significant decrease in bacterial growth was observed for g- $\mathrm{C}_{3} \mathrm{~N}_{4} @$ @u-NPs administered in combination with $\mathrm{H}_{2} \mathrm{O}_{2}$ at physiologically relevant concentrations $(100 \mu \mathrm{M})$. Importantly, biofilms, the main responsible for antibiotic resistance, were completely degraded by $\mathrm{g}-\mathrm{C}_{3} \mathrm{~N}_{4} @$ AuNPs in the presence of physiological $\mathrm{H}_{2} \mathrm{O}_{2}$ concentrations $(100 \mu \mathrm{M})$ as shown by the change in mass which was quantified by a standard crystal violet-based 
colorimetric assay. Additionally, by constructing a g- $\mathrm{C}_{3} \mathrm{~N}_{4} @ \mathrm{Au}$ NPs-based Band-Aid, the ability of the nanocomposites to decrease bacterial infection while accelerating wound healing was demonstrated in vivo. The authors employed Kunming mice with a wound on their back which were treated with the g- $\mathrm{C}_{3} \mathrm{~N}_{4} @$ Au-NPs-based Band-Aid in the presence of very low $\mathrm{H}_{2} \mathrm{O}_{2}$ concentrations (of only $10 \mu \mathrm{M} \mathrm{H}_{2} \mathrm{O}_{2}$ as compared to the concentrations commonly used in anti-infection wounds of $166 \mathrm{mM}$ to $1 \mathrm{M}$ ). The response to the infection was evaluated by harvesting the wound tissue followed by conducting CFU counts. After 3 days of treatment, the CFU counts showed efficient prevention of wound infection following treatment with g- $\mathrm{C}_{3} \mathrm{~N}_{4} @ A u-N P s$ and $\mathrm{H}_{2} \mathrm{O}_{2}$ treatment groups. Lastly, the authors assessed g- $\mathrm{C}_{3} \mathrm{~N}_{4} @$ @u-NPs' half-live and biodistribution profile following intravenous administration. While the nanocomposites half-lives in blood were determined to be $\sim 40$ min, biodistribution studies showed accumulation within lung tissue, thus suggesting lung infection as a potential target for g- $\mathrm{C}_{3} \mathrm{~N}_{4} @ A u-N P s$. As such, $\mathrm{C}_{3} \mathrm{~N}_{4} @ A u-N P s$ were evaluated in the context of MRSA-induced inflammation within a murine lung infection model. The amount of bacterial in lung together with a histology analysis conducted $96 \mathrm{~h}$ post-injection; demonstrated a similar amount of bacteria for the mice treated with nanozymes or vancomycin, which is currently the last treatment option for MRSA strains in the clinic.

The same group also explored a complete different approach for biofilm inhibition and destruction. ${ }^{109}$ Since, extracellular DNA is a fundamental structural constituent for the biofilm formation, the Qu group fabricated a nanozyme displaying DNase-like activity. The DNase-mimetic artificial enzyme (DMAE) was composed by $\mathrm{Fe}_{3} \mathrm{O}_{4} @ \mathrm{SiO}_{2}$ core-shell NPs further coated by an Au-based shell containing multiple CelV complexes. While CeIV was chosen due to its DNase-like activity, the paramagnetic properties of the $\mathrm{Fe}_{3} \mathrm{O}_{4} @ \mathrm{SiO}_{2}$ core were selected to facilitate the recovery and further reusability of the NPs by the use of an external magnet. The authors demonstrated the ability of DMAE to avoid biofilm formation and eradication if used in combination with conventional antibiotics. The biofilm prevention was assessed by the ability of DMAE-coated surfaces to inhibit both bacterial adhesion and biofilm formation. The results demonstrated a reduction of $\sim 92 \%$ in S. aureus attachment and much thinner biofilms for surfaces coated with DMAE as compared to the ones coated with native DNases. The ability of DMAE to degrade biofilms was assessed in the presence of ampicillin, levofloxacin, and rifampin. The results demonstrated biofilm destruction as shown by the enhanced decrease in CFU for films treated with the combination of DMAE and antibiotics as compared to antibiotics only. These results suggest that the destruction of the biofilms by DMAE increased the availability of the antibiotics to the cells thus increasing the antibiotics efficiency. Lastly, on an original approach, multifunctional nanozymes were used to catalyse the polymerisation and subsequent assembly of an antibacterial hydrogel. ${ }^{110}$ Copper oxide NPs (CuO-NPs), which display HRP-like activity, were used to generate carbon radicals by catalysing the reaction between $\mathrm{H}_{2} \mathrm{O}_{2}$ and hydrogen-donating mediators. GOx was also used in the system to generate $\mathrm{H}_{2} \mathrm{O}_{2}$ and also to ${ }_{V i}$ adjust othe

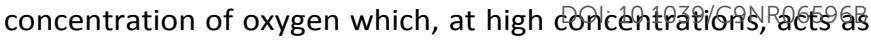
a strong inhibitor of the polymerization. The antibacterial properties of the as-prepared hydrogel against $E$. coli bacteria were attributed to the in situ production of ${ }^{\circ} \mathrm{OH}$ as a result of the reaction between CuO-NPs and glucose.

\subsection{Other therapeutic applications}

Multifunctional nanozymes have also been evaluated in the context of other therapeutic applications such as $A D$ or enzyme replacement therapy (ERT).

The key pathogenic mechanisms of $A D$, which is an intractable neurodegenerative disease currently affecting about thirty million people worldwide, ${ }^{111}$ are the aggregation of $A \beta$ into oligomers or fibrils accompanied by ROS production. ${ }^{112,113}$ Thus, recent strategies for $A D$ therapy involve the inhibition of $A \beta$ together with ROS scavenging or removal. ${ }^{114}$ Research efforts for $A D$ have employed multifunctional nanozymes for ROS scavenging (as reviewed in section 2.2) but also as protease mimics for $A \beta$ degradation.

On a first example, a nanocomposite of ceria NPs (CeO-NPs) and polyoxometalates (CeO-NP@POMs) was evaluated in the context of AD. ${ }^{115}$ While CeO-NPs were chosen due to their antioxidant activity which may protect the brain from oxidative stress; rare earth metal-substituted POMs were selected due to their ability to hydrolyse peptides. ${ }^{116-118}$ The authors fabricated CeO-NPs of about $3 \mathrm{~nm}$ in diameter and the CeONP@POMs were assembled upon deposition of the POMs onto the CeO-NPs surface acting as a ligand coordinated to the $\mathrm{Ce}$ ions (Celll and CelV). The hydrolytic effects of the CeONP@POMs on $A \beta$ were evaluated by matrix-assisted laser desorption ionization time-of-flight mass spectrometry (MALDI-TOF MS). Figure 6A shows how, following incubation for $24 \mathrm{~h}$ at $37^{\circ} \mathrm{C}$, the characteristic $A \beta 40$ peak decreases while several low molecular peaks appear. The proteolytic potential of CeO-NP@POMs was also assessed by atomic force microscopy and TEM showing the disappearance of the large fibrils upon incubation with CeO-NP@POMs (Figure 6B). The CeO-NP@POMs were evaluated in vitro demonstrating efficient inhibition of $A \beta$-mediated cytotoxicity as shown by cell viability assays in a PC12 nerve cell model (Figure $6 \mathrm{C}$ ). The CeO-NP@POMs were also able to decrease intracellular ROS levels by $68 \%$ in PC12 cells exposed to $A \beta$ as shown by flow cytometry using the dichlorofluorescein diacetate (DCFHDA) ${ }^{119}$ probe (Figure 6C). Finally, the CeO-NP@POMs were also evaluated in vivo. Biodistribution studies showed the lowest CeO-NP@POMs accumulation in heart and brain. Transport through the blood brain barrier (BBB) was assessed by measuring the tungsten levels by ICP-MS which showed a $0.54 \%$ efficiency for the $\mathrm{CeO}_{2}-\mathrm{NP} @ P O M s$ in crossing the BBB.

Molybdenum disulphide $\left(\mathrm{MoS}_{2}\right)$-NPs, which have shown antioxidant properties, ${ }^{120,121}$ have also been assessed in terms of inhibition of $A \beta$ aggregation. ${ }^{122} \mathrm{MoS}_{2}$-NPs demonstrated the ability to inhibit $A \beta$ aggregation by $60 \%$ as shown by the thioflavin $\mathrm{T}$ (ThT) probe, which emits fluorescence upon binding to a $\beta$-sheet structure. The results were further corroborated by AFM and TEM. The ability of $\mathrm{MoS}_{2}$-NPs to 
scavenge $A \beta$-induced ROS was assessed intracellularly employing the DCFH-DA fluorescence probe in SY5Y cells. The results, which show a dose-response decrease in ROS levels, highlight the potential of $\mathrm{MoS}_{2}$-NPs as multifunctional therapeutic agents in $A \beta$-related diseases. Furthermore, $\mathrm{MoS}_{2-}$ NPs were also able to block the formation of the $\mathrm{Ca}^{2+}$ channel in the cell membrane, which is induced by $A \beta$ aggregates.
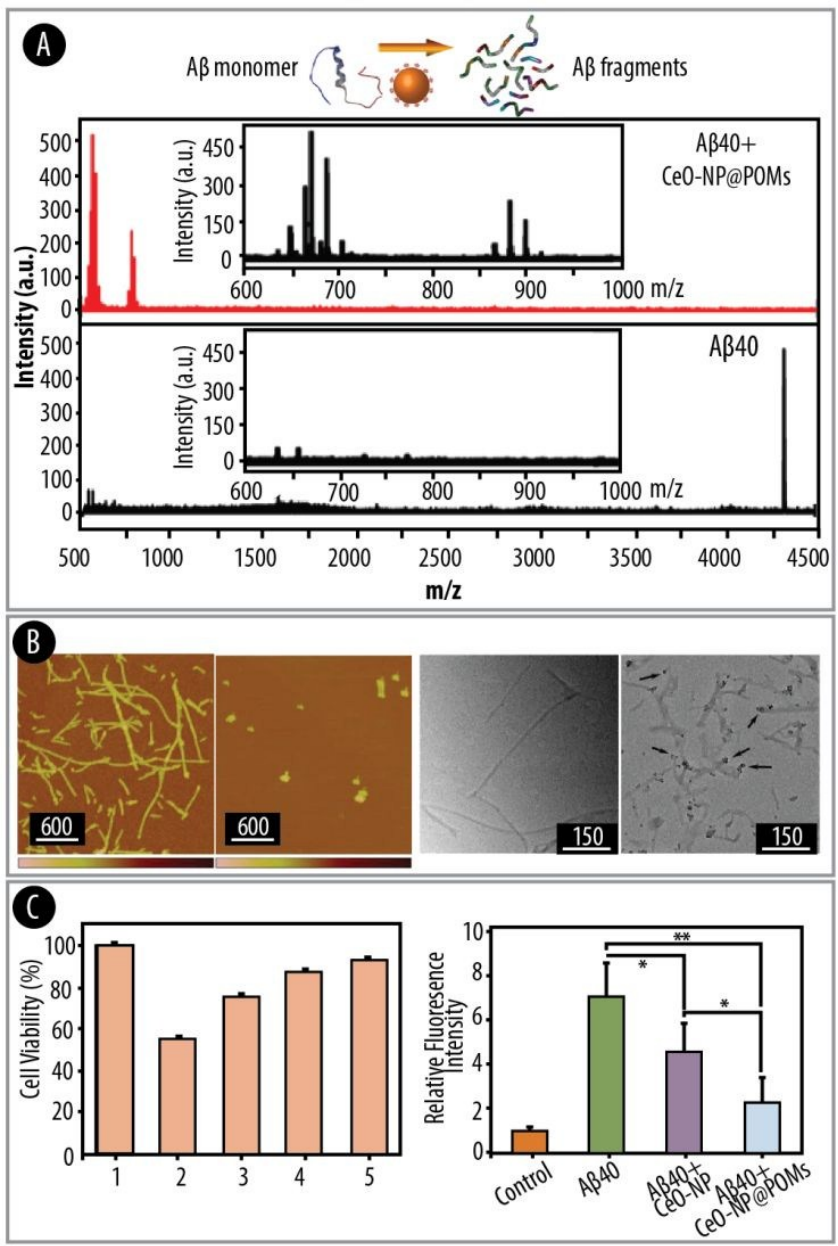

Figure 6. A) Scheme of CeO-NP@POMs as hydrolytic enzyme to degrade A $\beta 40$ monomers and MALDI-TOF MS of A 340 monomers untreated or treated with CeONP@POMs. B) (left) AFM images and (right) TEM images of A 40 fibrils untreated or treated with CeO-NP@POMs for 24 h. Scale bar: 600 nm (AFM) and 150 nm (TEM).C) (left) MTT assay of PC12 cells: 1) Control: A $\beta 40$ untreated, $A \beta 40$ with 2) 0 , 3) 40 , 4) 80 , 5) $150 \mu \mathrm{g} / \mathrm{mL}$ CeO-NP@POMs and (right) Generation of ROS in PC12 cells. $\left({ }^{*} p<0.05, * * p<0.01\right)$ Reprinted with permission from [115]. Copy right 2016 Elsevier B.V.

Finally, nanozymes have also been explored in the context of ERT in particular as potential therapy for hyperuricemia. ${ }^{123}$ Hyperuricemia is a disease induced by the deficiency of a digestive enzyme which causes the accumulation of over high levels of uric acid (UA) in plasma. ${ }^{124}$ These extremely high UA concentration results in vascular and renal disease amongst others. ${ }^{125,126}$ The authors entrapped the enzyme uricase and Pt-NPs within mesoporous silica particles (Uricase/Pt@Si-NPs) to form a tandem catalytic system. Uricase was able to specifically catalyse the degradation of UA producing $\mathrm{H}_{2} \mathrm{O}_{2}$ as a by-product, which was simultaneously depleted by the coencapsulated Pt-NPs. The as-prepared Uricase/Pt@Si-NPs demonstrated the ability to degrade physiological on

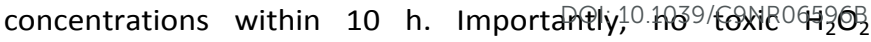
remained following UA degradation showing the efficiency of the tandem Uricase/Pt@Si-NPs. Following on, the authors also conducted in vivo studies on hyperuricemia mouse model. Following intravenous injection of Uricase/Pt@Si-NPs, the UA concentration in plasma was assessed for several time intervals. The results, which showed the lowest UA levels for mice treated with Uricase/Pt@Si-NPs at all the studied timepoints, provide new insights into development of efficient and friendly enzyme replacement therapy.

\section{Multifunctional nanozymes in regenerative medicine}

Multifunctional nanozymes have been studied in the context of stem cell therapy, which is a rapidly evolving area of research in regenerative medicine.

Due to the crucial role of $\mathrm{H}_{2} \mathrm{O}_{2}$ in the control of proliferation and cell death, ${ }^{127-130}$ research efforts have mainly employed iron-based nanozymes to catalyse the breakdown of $\mathrm{H}_{2} \mathrm{O}_{2}$ and thus stimulate stem cells growth and proliferation. Additionally, the magnetic properties of the iron-based nanozymes also allow for cell tracking. ${ }^{131,132}$

One of the first studies was reported by the Chen group which employed $\mathrm{Fe}_{3} \mathrm{O}_{4}$-NPs to promote the proliferation of human mesenchymal stem cells (hMSCs). ${ }^{133}$ The authors demonstrated that the enhanced proliferation of hMSCs was due to the $\mathrm{Fe}_{3} \mathrm{O}_{4}$-NPs ability in decreasing intracellular $\mathrm{H}_{2} \mathrm{O}_{2}$ but also to the released free iron ions upon degradation of the $\mathrm{Fe}_{3} \mathrm{O}_{4}$-NPs within the cell lysosomes. The results showed how the free iron ions could accelerate the cell cycle progression by alteration of the iron ions on the expression of the cell cycle protein regulators.

Following studies making use of iron-based nanozymes were reported by Murohara and co-workers. ${ }^{134}$ In particular, $\mathrm{Fe}_{3} \mathrm{O}_{4^{-}}$ NPs were used in the context of therapeutic angiogenesis with cell transplantation. Cell transplantation has emerged as a powerful strategy for severe ischemic diseases since it promotes the formation of collateral vessels and the subsequent angiogenesis by the release of several angiogenic growth factors. ${ }^{135,136}$ However, to overcome the limitations of the conventional injection-based cell therapy, which currently results in a very poor response, the authors made use of the magnetic properties of $\mathrm{Fe}_{3} \mathrm{O}_{4}$-NPs. They created multi-layered three-dimensional (3D) hMSCs sheets to be subsequently implanted within the ischemic tissue. The hMSCs were incubated with lipid coated $\mathrm{Fe}_{3} \mathrm{O}_{4}$-NPs and, upon cell internalization, the magnetic properties of the particles were employed to create pile-ups of about 10-15 layers of cells with around $300 \mu \mathrm{m}$ in thickness. Following implantation within the ischemic tissue, the enhanced angiogenesis by the multilayered sheet group as compared to the injected cells, was demonstrated by both laser Doppler blood flowmetry and histological capillary density. Furthermore, the authors also corroborated the antioxidant peroxidase-like activity of the 
$\mathrm{Fe}_{3} \mathrm{O}_{4}$-NPs since cell incubation with $\mathrm{Fe}_{3} \mathrm{O}_{4}-\mathrm{NPs}$ resulted in enhanced proliferation.

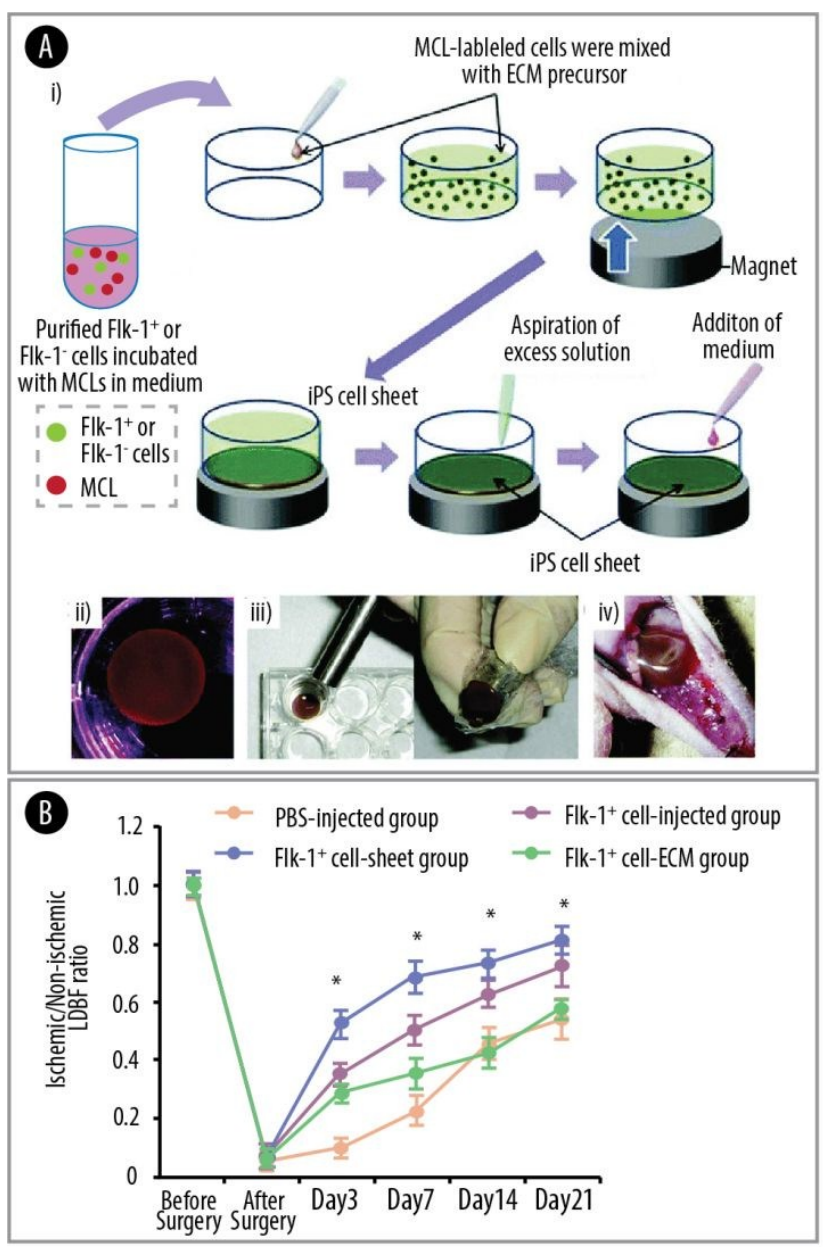

Figure 7. A) $\mathrm{Fe}_{3} \mathrm{O}_{4}-\mathrm{NPS}$ facilitated formation of iPS cell sheets for reparative angiogenesis. i) Procedure for construction of the iPS cell-derived cell sheet, ii) An alnico magnet was positioned on the surface of the culture medium. The Flk- $1^{+}$cell sheet floated up to the surface of the culture medium without disruption. iii) The magnetized $\mathrm{Flk}-1^{+}$cell sheet attached to an alnico magnet covered with polyvinylidene difluoride membrane via a magnetic force. iv) $\mathrm{Flk}-1^{+}$cell sheets were placed on the adductor muscles of nude mice using the alnico magnet. B) Quantitative analysis of the ischemic/normal laser Doppler blood flow (LDBF) ratios in the Flk-1+ $1^{+}$cell-sheet, Flk-1+ ${ }^{+}$cell-injected, Flk-1+ cell-ECM and control phosphatebuffer saline (PBS) groups. ${ }^{*} p<0.05$ vs. Flk- $1^{+}$cell-injected group. Reprinted with permission from [31].Copyright (2013) Nature Publishing Group.

The same group also reported a follow up study, were induced pluripotent stem cells (iPSCs)-derived fetal liver kinase-1 positive $\left(\mathrm{Flk}-\mathrm{1}^{+}\right)$cells were also employed in the context of reparative angiogenesis. ${ }^{31}$ Similarly as previously described, the Flk-1+ $1^{+}$cells were loaded with $\mathrm{Fe}_{3} \mathrm{O}_{4}-\mathrm{NPs}$ to create 3D multilayered cell sheets. The local implantation of the 3D multilayered cell sheets in a hind limb ischemia mouse model resulted in enhanced angiogenesis. Figure 7A shows how the cell sheets were placed on the mice's adductor muscles using a magnet. Next, Figure 7B depicts how the cell sheets induced angiogenesis more effectively as compared to the conventional direct injection of cells. The authors attribute the angiogenic effect to the peroxidase-like antioxidant activity of the $\mathrm{Fe}_{3} \mathrm{O}_{4}$-NPs since cell loading with $\mathrm{Fe}_{3} \mathrm{O}_{4}$-NPs inhibited both the induced cell death by a glutathione-depleting agent and also the expression of the Bax pro-apoptotidphotein? Aps serch, these results highlight how the combination of magnetic properties that allow for enrichment and separation, together with the catalytic activities of the $\mathrm{Fe}_{3} \mathrm{O}_{4}-\mathrm{NPs}$ result in a promising approach for therapeutic angiogenesis. ${ }^{4,31}$

Finally, the effect of $\mathrm{Fe}_{3} \mathrm{O}_{4}$-NPs onto stem cells has been also evaluated in the context of cancer therapy. By means of their peroxidase-like activity, poly(L-lysine)-modified $\mathrm{Fe}_{3} \mathrm{O}_{4}$-NPs were able to reduce intracellular $\mathrm{H}_{2} \mathrm{O}_{2}$ which translated into increased proliferation of cancer stem cells from U251 glioblastoma. ${ }^{137}$

\section{Conclusions}

In this review, we have highlighted a number of recent advances of multifunctional nanozymes and their applications in cancer therapy, protecting cells and tissues against oxidative stress, eradicating bacteria, as well as regenerative medicine. Due to simple preparation, low cost, easy storage, and excellent stability, nanozymes could gradually replace the use of natural enzymes in the biomedical field. Although the progress made to date is encouraging, there are still remaining challenges. Firstly, most nanozymes do not catalyse only one specific substrate like natural enzymes do. Although possessing multienzyme-like activities may be beneficial, in some cases, poor substrate selectivity may lead to undesirable side reactions in biological settings. Therefore, improving the selectivity of nanozymes is a great challenge to be tackled. Secondly, the catalytic activities of most nanozymes are still lower than the corresponding natural enzymes, and at times cannot meet the requirements of practical applications. While this could be overcome by tailoring the concentration of nanozymes to be used, this may lead to an issue of toxicity from concentration-dependent effect. Efforts need to be paid to construct nanozymes with high catalytic efficiency. Next, many catalytic mechanisms of nanozymes are still unclear and remain to be fully elucidated. A better understanding of the catalytic mechanisms may reveal structure-activity relationship and provide better regulation of catalytic efficiency and substrate selectivity. Collaborative efforts from various disciplines, such as computational studies, machine learning, and artificial intelligent techniques, can be combined together to elucidate catalytic mechanisms of nanozymes. Finally, improving batch-to-batch reproducibility of nanozymes will be vital in clinical translation.

\section{Conflicts of interest}

There are no conflicts to declare.

\section{Acknowledgements}

This work was supported by the Danish Council for Independent Research (XL, Grant No. 6111-00298B) and the Lundbeck Foundation, Denmark (LH-R, Grant No. R163-2013- 
15402). R.C. acknowledges the support from the Australian Research Council Discovery Early Career Researcher Award (ARC DECRA DE170100068) and the UNSW Scientia Fellowship.

\section{References}

1 R. Ragg, M. N. Tahir and W. Tremel, Eur. J. Inorg. Chem., 2016, 2016, 1906-1915.

2 Y. Zhou, B. Liu, R. Yang and J. Liu, Bioconjug. Chem., 2017, 28, 2903-2909.

3 X. Wang, Y. Hu and H. Wei, Inorg. Chem. Front., 2016, 3, 41-60.

$4 \quad$ J. Wu, S. Li and H. Wei, Nanoscale Horizons, 2018, 3, 367382.

5 J. Wu, S. Li and H. Wei, Chem. Commun., 2018, 54, 65206530.

6 D. Jiang, D. Ni, Z. T. Rosenkrans, P. Huang, X. Yan and W. Cai, Chem. Soc. Rev.

$7 \quad$ L. Gao, K. Fan and X. Yan, Theranostics, 2017, 7, 32073227.

J. Wu, X. Wang, Q. Wang, Z. Lou, S. Li, Y. Zhu, L. Qin and H. Wei, Chem. Soc. Rev., 2019, 48, 1004-1076. H. Wei and E. Wang, Chem. Soc. Rev., 2013, 42, 6060.

10 X. Wang, X. J. Gao, L. Qin, C. Wang, L. Song, Y.-N. Zhou, G. Zhu, W. Cao, S. Lin and L. Zhou, Nat. Commun., 2019, 10, 704.

11 S. Lin, Y. Zhang, W. Cao, X. Wang, L. Qin, M. Zhou and H. Wei, Dalt. Trans., 2019, 48, 1993-1999.

12 Y. Hu, X. J. Gao, Y. Zhu, F. Muhammad, S. Tan, W. Cao, S. Lin, Z. Jin, X. Gao and H. Wei, Chem. Mater., 2018, 30, 6431-6439.

13 C. P. Liu, T. H. Wu, Y. L. Lin, C. Y. Liu, S. Wang and S. Y. Lin, Small, 2016, 12, 4127-4135.

X. Shen, W. Liu, X. X. Gao, Z. Lu, X. Wu and X. X. Gao, J. Am. Chem. Soc., 2015, 137, 15882-15891.

15 G. Fang, W. Li, X. Shen, J. M. Perez-Aguilar, Y. Chong, X. Gao, Z. Chai, C. Chen, C. Ge and R. Zhou, Nat. Commun., 2018, 9, 129.

16 S. Fan, M. Zhao, L. Ding, H. Li and S. Chen, Biosens. Bioelectron., 2017, 89, 846-852.

17 J. Liu, L. Meng, Z. Fei, P. J. Dyson, X. Jing and X. Liu, Biosens. Bioelectron., 2017, 90, 69-74.

18 Y. Zhang, Z. Wang, X. Li, L. Wang, M. Yin, L. Wang, N. Chen, C. Fan and H. Song, Adv. Mater., 2016, 28, 1387-1393.

A. A. Vernekar, D. Sinha, S. Srivastava, P. U. Paramasivam, P. D'Silva, G. Mugesh, P. D'Silva and G. Mugesh, Nat. Commun., 2014, 5, 5301. J. Yao, Y. Cheng, M. Zhou, S. Zhao, S. Lin, X. Wang, J. Wu, S. Li and H. Wei, Chem. Sci., 2018, 9, 2927-2933. M. M. Behrens, S. S. Ali, D. N. Dao, J. Lucero, G. Shekhtman, K. L. Quick and L. L. Dugan, Science, 2007, 318, 1645-7. L. L. Dugan, L. Tian, K. L. Quick, J. I. Hardt, M. Karimi, C. Brown, S. Loftin, H. Flores, S. M. Moerlein, J. Polich, S. D. Tabbal, J. W. Mink and J. S. Perlmutter, Ann. Neurol., 2014, 76, 393-402.
Tsai and J. M. Tour, Proc. Natl. Acad. Sci. U. S. A 2012015 online $112,2343-8$.

DOI: 10.1039/C9NR06596B

T. Xue, B. Peng, M. Xue, X. Zhong, C.-Y. Chiu, S. Yang, Y. Qu, L. Ruan, S. Jiang, S. Dubin, R. B. Kaner, J. I. Zink, M. E. Meyerhoff, X. Duan and Y. Huang, Nat. Commun., 2014, 5, 3200.

M. Saeed and L. Deng, Int. J. Greenh. Gas Control, 2016, 53, 254-262.

F. Natalio, R. André, A. F. Hartog, B. Stoll, K. P. Jochum, R. Wever and W. Tremel, Nat. Nanotechnol., 2012, 7, 530535.

M. Kluenker, M. Nawaz Tahir, R. Ragg, K. Korschelt, P. Simon, T. E. Gorelik, B. Barton, S. I. Shylin, M. Panthöfer, J. Herzberger, H. Frey, V. Ksenofontov, A. Möller, U. Kolb, J. Grin and W. Tremel, Chem. Mater., 2017, 29, 1134-1146. V. Petkov, B. N. Wanjala, R. Loukrakpam, J. Luo, L. Yang, C.J. Zhong and S. Shastri, Nano Lett., 2012, 12, 4289-99. D. Hu, Z. Sheng, S. Fang, Y. Wang, D. Gao, P. Zhang, P. Gong, Y. Ma and L. Cai, Theranostics, 2014, 4, 142-153. J. Bai, X. Jia, W. Zhen, W. Cheng and X. Jiang, J. Am. Chem. Soc., 2018, 140, 106-109.

T. Kito, R. Shibata, M. Ishii, H. Suzuki, T. Himeno, Y. Kataoka, Y. Yamamura, T. Yamamoto, N. Nishio, S. Ito, Y. Numaguchi, T. Tanigawa, J. K. Yamashita, N. Ouchi, H. Honda, K. Isobe and T. Murohara, Sci. Rep., 2013, 3, 1418. Y. Xia, H. Chen, Y. Zhao, F. Zhang, X. Li, L. Wang, M. D. Weir, J. Ma, M. A. Reynolds and N. Gu, Mater. Sci. Eng. C, 2019, 98, 30-41.

Y. Huang, J. Ren and X. Qu, Chem. Rev., 2019, 119, 43574412

M. Liang and X. Yan, Acc. Chem. Res., 2019, 52, 2190-2200. J. A. Ramos-Vara, Vet. Pathol., 2005, 42, 405-426.

C. M. van der Loos, J. Histotechnol., 2010, 33, 31-40.

A. M. Gown, Mod. Pathol., 2008, 21, S8-S15.

J. Liu, W. Zhang, H. Zhang, Z. Yang, T. Li, B. Wang, X. Huo, R. Wang and H. Chen, Chem. Commun., 2013, 49, 4938. J. Zhuang, K. Fan, L. Gao, D. Lu, J. Feng, D. Yang, N. Gu, Y. Zhang, M. Liang and X. Yan, Mol. Pharm., 2012, 9, 19831989.

K. Fan, C. Cao, Y. Pan, D. Lu, D. Yang, J. Feng, L. Song, M Liang and X. Yan, Nat. Nanotechnol., 2012, 7, 459-464. D. Zhang, Y.-X. Zhao, Y.-J. Gao, F.-P. Gao, Y.-S. Fan, X.-J. Li, Z.-Y. Duan and H. Wang, J. Mater. Chem. B, 2013, 1, 5100. M. Huo, L. Wang, Y. Chen and J. Shi, Nat. Commun., 2017, 8, 357.

N. L. Oleinick, R. L. Morris and I. Belichenko, Photochem. Photobiol. Sci., 2002, 1, 1-21.

J. Kim, H. R. Cho, H. Jeon, D. Kim, C. Song, N. Lee, S. H. Choi and T. Hyeon, J. Am. Chem. Soc., 2017, 139, 10992-10995. Z. Ma, M. Zhang, X. Jia, J. Bai, Y. Ruan, C. Wang, X. Sun and X. Jiang, Small, 2016, 12, 5477-5487.

R. B. Bjorklund and B. Liedberg, J. Chem. Soc. Chem. Commun., 1986, 1293.

Y. Song, Q. Shi, C. Zhu, Y. Luo, Q. Lu, H. Li, R. Ye, D. Du and Y. Lin, Nanoscale, 2017, 9, 15813-15824.

L. Fan, X. Xu, C. Zhu, J. Han, L. Gao, J. Xi and R. Guo, ACS Appl. Mater. Interfaces, 2018, 10, 4502-4511. 
49 N. H. Levi-Polyachenko, E. J. Merkel, B. T. Jones, D. L. Carroll and J. H. Stewart, Mol. Pharm., 2009, 6, 1092-1099. C. Liang, S. Diao, C. Wang, H. Gong, T. Liu, G. Hong, X. Shi, H. Dai and Z. Liu, Adv. Mater., 2014, 26, 5646-5652. Q. Liu, C. Sun, Q. He, D. Liu, A. Khalil, T. Xiang, Z. Wu, J. Wang and L. Song, Chem. Commun. (Camb)., 2015, 51, 10054-7. L. Au, D. Zheng, F. Zhou, Z.-Y. Li, X. Li and Y. Xia, ACS Nano, 2008, 2, 1645-1652.

53 X. Cheng, R. Sun, L. Yin, Z. Chai, H. Shi and M. Gao, Adv. Mater., 2017, 29, 1604894.

54 C. C. Winterbourn, Nat. Chem. Biol., 2008, 4, 278-286.

55 M. Schieber and N. S. Chandel, Curr. Biol., 2014, 24, R453R462.

56 T. Finkel, J. Biol. Chem., 2012, 287, 4434-4440.

L. A. Sena and N. S. Chandel, Mol. Cell, 2012, 48, 158-167. F. Giacco and M. Brownlee, Circ. Res., 2010, 107, 10581070.

59 T. Tiganis, Trends Pharmacol. Sci., 2011, 32, 82-89.

60 J. K. Andersen, Nat. Med., 2004, 10, S18-S25.

61

P. Jenner and C. W. Olanow, Neurology, 1996, 47, S161-70. R. A. Cairns, I. S. Harris and T. W. Mak, Nat. Rev. Cancer, 2011, 11, 85-95.

63 B. Xiong, R. Xu, R. Zhou, Y. He and E. S. Yeung, Talanta, 2014, 120, 262-267.

64 J. Dove, Environ. Educ. Res., 1996, 2, 89-100.

65 S. Shibuya, Y. Ozawa, K. Watanabe, N. Izuo, T. Toda, K. Yokote and T. Shimizu, PLoS One, 2014, 9, e109288. X. Mu, J. Wang, Y. Li, F. Xu, W. Long, L. Ouyang, H. Liu, Y. Jing, J. Wang, H. Dai, Q. Liu, Y. Sun, C. Liu and X.-D. Zhang, ACS Nano, 2019, acsnano.8b08045.

M. Moglianetti, E. De Luca, D. Pedone, R. Marotta, T. Catelani, B. Sartori, H. Amenitsch, S. F. Retta and P. P. Pompa, Nanoscale, 2016, 8, 3739-3752. M. Aioub, S. R. Panikkanvalappil and M. A. El-Sayed, ACS Nano, 2017, 11, 579-586. X. Huang, Z. Zhao, L. Cao, Y. Chen, E. Zhu, Z. Lin, M. Li, A. Yan, A. Zettl, Y. M. Wang, X. Duan, T. Mueller and Y. Huang, Science, 2015, 348, 1230-4.

F. Xiong, H. Wang, Y. Feng, Y. Li, X. Hua, X. Pang, S. Zhang, L. Song, Y. Zhang and N. Gu, Sci. Rep., 2015, 5, 8579. C. M. Grau and L. A. Greene, in Methods in molecular biology (Clifton, N.J.), 2012, vol. 846, pp. 201-211. L. Stefanis, K. E. Larsen, H. J. Rideout, D. Sulzer and L. A Greene, J. Neurosci., 2001, 21, 9549-60. Z. Huang, P. Zhang and C.-F. Liu, Neurosci. Lett., 2009, 454, 203-208. D. J. Selkoe, Cell, 1989, 58, 611-2. Z. Wang, K. Dong, Z. Liu, Y. Zhang, Z. Chen, H. Sun, J. Ren and X. Qu, Biomaterials, 2017, 113, 145-157.

N. Barraud, B. G. Kardak, N. R. Yepuri, R. P. Howlin, J. S. Webb, S. N. Faust, S. Kjelleberg, S. A. Rice and M. J. Kelso, Angew. Chemie Int. Ed., 2012, 51, 9057-9060.

77 Y. Li, K. Fukushima, D. J. Coady, A. C. Engler, S. Liu, Y. Huang, J. S. Cho, Y. Guo, L. S. Miller, J. P. K. Tan, P. L. R. Ee, W. Fan, Y. Y. Yang and J. L. Hedrick, Angew. Chemie Int. Ed.,

2013, 52, 674-678.

View Article Online

78
G. G. Anderson, J. J. Palermo, J. D. SeRilling, QR. R'R Heuser and S. J. Hultgren, Science (80-. )., 2003, 301, 105107.

R. Liu, X. Chen, S. P. Falk, K. S. Masters, B. Weisblum and S. H. Gellman, J. Am. Chem. Soc., 2015, 137, 2183-2186. W.-Y. Chen, H.-Y. Chang, J.-K. Lu, Y.-C. Huang, S. G. Harroun, Y.-T. Tseng, Y.-J. Li, C.-C. Huang and H.-T. Chang, Adv. Funct. Mater., 2015, 25, 7189-7199.

Y. Zhao, Y. Tian, Y. Cui, W. Liu, W. Ma and X. Jiang, J. Am. Chem. Soc., 2010, 132, 12349-12356.

Q. Li, S. Mahendra, D. Y. Lyon, L. Brunet, M. V. Liga, D. Li and P. J. J. Alvarez, Water Res., 2008, 42, 4591-4602. F. Hossain, O. J. Perales-Perez, S. Hwang and F. Román, Sci. Total Environ., 2014, 466-467, 1047-1059.

A. Azam, A. S. Ahmed, M. Oves, M. S. Khan, S. S. Habib and A. Memic, Int. J. Nanomedicine, 2012, 7, 6003.

D. Dhanasekaran, S. Latha, S. Saha, N. Thajuddin and A. Panneerselvam, Int. J. Green Nanotechnol., 2011, 3, 72-82. L. Rizzello, R. Cingolani and P. P. Pompa, Nanomedicine, 2013, 8, 807-821.

H. Y. Chang, J. Cang, P. Roy, H.-T. T. Chang, Y. C. Huang and C. C. Huang, ACS Appl. Mater. Interfaces, 2014, 6, 83058312.

L. Gao, K. M. Giglio, J. L. Nelson, H. Sondermann and A. J. Travis, Nanoscale, 2014, 6, 2588-2593.

L. Gao, Y. Liu, D. Kim, Y. Li, G. Hwang, P. C. Naha, D. P. Cormode and H. Koo, Biomaterials, 2016, 101, 272-284.

W.-Y. Pan, C.-C. Huang, T.-T. Lin, H.-Y. Hu, W.-C. Lin, M.-J. Li and H.-W. Sung, Nanomedicine Nanotechnology, Biol. Med., 2016, 12, 431-438.

L. Gao, J. Zhuang, L. Nie, J. Zhang, Y. Zhang, N. Gu, T. Wang, J. Feng, D. Yang, S. Perrett and X. Yan, Nat. Nanotechnol., 2007, 2, 577-583.

N. Takahashi and B. Nyvad, J. Dent. Res., 2011, 90, 294303.

T. Beikler and T. F. Flemmig, Periodontol. 2000, 2011, 55, 87-103.

H. Koo, M. L. Falsetta and M. I. Klein, J. Dent. Res., 2013, 92, 1065-73.

W. H. Bowen, Odontology, 2013, 101, 9-14.

G. J. Moran, A. Krishnadasan, R. J. Gorwitz, G. E. Fosheim, L. K. McDougal, R. B. Carey and D. A. Talan, N. Engl. J. Med., 2006, 355, 666-674.

M. C. Enright, D. A. Robinson, G. Randle, E. J. Feil, H. Grundmann and B. G. Spratt, Proc. Natl. Acad. Sci. U. S. A., 2002, 99, 7687-92.

P. A. Hyslop, D. B. Hinshaw, I. U. Scraufstatter, C. G. Cochrane, S. Kunz and K. Vosbeck, Free Radic. Biol. Med., 1995, 19, 31-37.

M. Fenech, J. Crott, J. Turner and S. Brown, Mutagenesis, 1999, 14, 605-612.

S. Shi, S. Wu, Y. Shen, S. Zhang, Y. Xiao, X. He, J. Gong, Y. Farnell, Y. Tang, Y. Huang and L. Gao, Theranostics, 2018, 8, 6149-6162.

S. Cai, X. Jia, Q. Han, X. Yan, R. Yang and C. Wang, Nano Res., 2017, 10, 2056-2069. 
102 T. Xue, S. Jiang, Y. Qu, Q. Su, R. Cheng, S. Dubin, C.-Y. Chiu, R. Kaner, Y. Huang and X. Duan, Angew. Chemie Int. Ed. 2012, 51, 3822-3825.

103 X. He, L. Tan, D. Chen, X. Wu, X. Ren, Y. Zhang, X. Meng and F. Tang, Chem. Commun., 2013, 49, 4643.

104 S. Ge, F. Liu, W. Liu, M. Yan, X. Song and J. Yu, Chem. Commun., 2014, 50, 475-477.

105 X. Zheng, Q. Liu, C. Jing, Y. Li, D. Li, W. Luo, Y. Wen, Y. He, Q. Huang, Y.-T. Long and C. Fan, Angew. Chemie Int. Ed., 2011, 50, 11994-11998.

106 Y. Jv, B. Li and R. Cao, Chem. Commun., 2010, 46, 8017.

$107+$ Zhenyuan Zhang, $\ddagger$ Alexander Berg, *,$\ddagger$ Haim Levanon, $\dagger$ and Richard W. Fessenden and + Dan Meisel*, DOI:10.1021/JA034830Z.

108 J. Tian, Q. Liu, A. M. Asiri, A. H. Qusti, A. O. Al-Youbi and X. Sun, Nanoscale, 2013, 5, 11604.

109 Z. Chen, H. Ji, C. Liu, W. Bing, Z. Wang and X. Qu, Angew. Chemie Int. Ed., 2016, 55, 10732-10736.

110 Y. Ye, L. Xiao, B. H. Bin He, Q. Zhang, T. Nie, X. Yang, D. Wu, H. Cheng, P. Li and Q. Wang, J. Mater. Chem. B, 2017, 5, 1518-1524.

111 R. Brookmeyer, E. Johnson, K. Ziegler-Graham and H. M. Arrighi, Alzheimer's Dement., 2007, 3, 186-191.

112 T. Arai, T. Araya, D. Sasaki, A. Taniguchi, T. Sato, Y. Sohma and M. Kanai, Angew. Chemie Int. Ed., 2014, 53, 82368239.

113 W. R. Markesbery, Free Radic. Biol. Med., 1997, 23, 134147.

114 M. S. Wolfe, Nat. Rev. Drug Discov., 2002, 1, 859-866.

115 Y. Guan, M. Li, K. Dong, N. Gao, J. Ren, Y. Zheng and X. Qu, Biomaterials, 2016, 98, 92-102.

116 G. Absillis and T. N. Parac-Vogt, Inorg. Chem., 2012, 51, 9902-9910.

117 K. Stroobants, E. Moelants, H. G. T. Ly, P. Proost, K. Bartik and T. N. Parac-Vogt, Chem. - A Eur. J., 2013, 19, 28482858.

118 H. G. T. Ly, G. Absillis, R. Janssens, P. Proost and T. N. Parac-Vogt, Angew. Chemie Int. Ed., 2015, 54, 7391-7394.

119 Z. Chen, Z. Li, J. Wang, E. Ju, L. Zhou, J. Ren and X. Qu, Adv. Funct. Mater., 2014, 24, 522-529.

120 X.-D. Zhang, J. Zhang, J. Wang, J. Yang, J. Chen, X. Shen, J. Deng, D. Deng, W. Long, Y.-M. Sun, C. Liu and M. Li, ACS Nano, 2016, 10, 4511-4519.

121 R. Rezaei-Sadabady, A. Eidi, N. Zarghami and A. Barzegar, Artif. Cells, Nanomedicine, Biotechnol., 2016, 44, 128-134.

122 Q. Han, S. Cai, L. Yang, X. Wang, C. Qi, R. Yang and C. Wang, ACS Appl. Mater. Interfaces, 2017, 9, 21116-21123.

123 X. Liu, Z. Zhang, Y. Zhang, Y. Guan, Z. Liu, J. Ren and X. Qu, Adv. Funct. Mater., 2016, 26, 7921-7928.

124 D. Chen, Q. Wang, J. Jin, P. Wu, H. Wang, S. Yu, H. Zhang and C. Cai, Anal. Chem., 2010, 82, 2448-2455.

125 R. J. Johnson, S. D. Kivlighn, Y. G. Kim, S. Suga and A. B. Fogo, Am. J. Kidney Dis., 1999, 33, 225-34.

126 A. K. Bhargava, H. Lal and C. S. Pundir, J. Biochem. Biophys. Methods, 1999, 39, 125-36.

127 C. Nicco, A. Laurent, C. Chereau, B. Weill and F. Batteux, Biomed. Pharmacother., 2005, 59, 169-174.

R. Schreck, P. Rieber and P. A. Baeuerle, EMBO dry $1991_{0} 10$, 2247-58.

DOI: 10.1039/C9NR06596B

A. M. Rodríguez, P. M. Carrico, J. E. Mazurkiewicz and J. A. Meléndez, Free Radic. Biol. Med., 2000, 29, 801-13.

S. Li, T. Yan, J. Q. Yang, T. D. Oberley and L. W. Oberley, Cancer Res., 2000, 60, 3927-39.

J. W. M. Bulte, T. Douglas, B. Witwer, S.-C. Zhang, E. Strable, B. K. Lewis, H. Zywicke, B. Miller, P. van Gelderen, B. M. Moskowitz, I. D. Duncan and J. A. Frank, Nat. Biotechnol., 2001, 19, 1141-1147.

R. Weissleder, H.-C. Cheng, A. Bogdanova and A. Bogdanov, J. Magn. Reson. Imaging, 1997, 7, 258-263.

D. M. Huang, J. K. Hsiao, Y. C. Chen, L. Y. Chien, M. Yao, Y. K. Chen, B. S. Ko, S. C. Hsu, L. A. Tai, H. Y. Cheng, S. W. Wang, C. S. Yang and Y. C. Chen, Biomaterials, 2009, 30, 3645-3651.

M. Ishii, R. Shibata, Y. Numaguchi, T. Kito, H. Suzuki, K. Shimizu, A. Ito, H. Honda and T. Murohara, Arterioscler. Thromb. Vasc. Biol., 2011, 31, 2210-2215.

T. Kinnaird, E. Stabile, M. S. Burnett, M. Shou, C. W. Lee, S. Barr, S. Fuchs and S. E. Epstein, Circulation, 2004, 109, 1543-1549.

M. Ishii, Y. Numaguchi, K. Okumura, R. Kubota, X. Ma, R Murakami, K. Naruse and T. Murohara, Atherosclerosis, 2009, 206, 109-18.

X. Wang, Q. Tu, B. Zhao, Y. An, J. J.-C. Wang, W. Liu, M.-S. Yuan, S. M. Ahmed, J. Xu, R. Liu, Y. Zhang and J. J.-C. Wang, Biomaterials, 2013, 34, 1155-1169. 